\title{
KOMATIITIC EXPLOSIVE VOLCANISM AND ITS TECTONIC SETTING IN FINLAND, THE FENNOSCANDIAN (BALTIC) SHIELD
}

\author{
MATTI SAVERIKKO
}

SAVERIKKO, MATTI, 1990: Komatiitic explosive volcanism and its tectonic setting in Finland, the Fennoscandian (Baltic) Shield. Bull. Geol. Soc. Finland 62, Part 1, $3-38$.

The variously explosive komatiitic volcanism in Finland was virtually confined to the Archaean continental segment, where it occurred in the Lapland and Kuhmo-Suomussalmi greenstone belts between $3.0 \mathrm{Ga}$ and $2.5 \mathrm{Ga}$, in the continental borderland at $1.97 \mathrm{Ga}$, and in the continental shelf break 1.91-1.88 Ga ago.

The Archaean continent comprised the Samian craton, which stabilized at 3.1-3.0 Ga before splitting into an array of sialic megablocks. Except for the NWtrending rifts, the linear crustal openings of the Fennoscandian greenstone belts constituted a radial swarm of aulacogens caused by domal uplift in connection with shield-wide mantle upwelling. Diapirism resulted in the Lapponian pyroclastic komatiite zone of mantle-activated rifting and in the large Solovetski mantle plume in the USSR, along which continental breakup reached no more than an embryonic stage of divergence.

The Finnish greenstone belts underwent three periods of supracrustal evolution from cratonic deposition and/or continental rifting to oceanic or mantle-activated rifting. The extensional stage of the greenstone-belt genesis is recognizable in Lapland but not in the Kuhmo-Suomussalmi area, in the ductile? periphery of the continental plate, where sagduction obscured the geological history.

In Lapland, the komatiitic central-vents opened at rift-aulacogen intersections. Some signs of volcanic bursting, albeit obscure, can be traced in the earlier ultramafics, namely in the initial komatiitic greenstones beneath the cratonic metasediments and in those associated with bimodal metavolcanics. Pyroclastics formed in all the komatiitic rock types but the pyroxene peridotitic komatiite (MgO 18 $30 \mathrm{wt} \%$, anhydrous basis) was the predominant substance to extrude in enormous magmatic explosions during the terminal stage of mantle upwelling.

After the Karelian anorogenic period, mantle activity produced two ophiolitic suites from the mantle plumes $1.97-1.96 \mathrm{Ga}$ ago. The one at Outokumpu brought about volcaniclastic komatiites under shallow-water to terrestrial conditions. The preferred environment was the Raahe-Ladoga marginal rift, of basin-range nature.

At the peak of the Svecofennian orogeny $(1.90-1.87 \mathrm{Ga})$, some minor komatiites with negligible ejecta discharged at the continental edge, forming the extreme member of Bothnian volcanism.

Key words: komatiite, volcanism, pyroclastics, greenstone belts, lithostratigraphy plate tectonics, rifting, aulacogens, Baltic Shield, Precambrian, Finland.

Matti Saverikko: Hakamäki 4 G 97, SF-02120 Espoo, Finland. 


\section{Introduction}

Although pyroclastics are not characteristics of the komatiites (Arndt et al. 1979), they are found in

- Africa (Nisbet et al. 1977; Williams 1979; Viljoen et al. 1983),

- Australia (McCall 1973; Sun and Nesbitt 1978; Nisbet and Chinner 1981; Page and Schmulian 1981; Binns et al. 1982),

- Canada (Kretschmar and Kretschmar 1975; Gelinas et al. 1977; Karvinen 1978; Jensen and Langford 1985),

- India (Gupta et al. 1982),

- South America (Echeverria and Aitken 1986), and

- Fennoscandia: Finland, Norway, Sweden, Soviet Karelia and the Kola Peninsula.

Such rocks usually constitute only a minor part of the ultramafic volcanic pile. The exception is in the Fennoscandian (Baltic) Shield, in Finland in particular, where komatiitic explosive volcanism was regional in extent; but some of the exposures are known only from preliminary notes for the present study. Volcaniclastic komatiites have also been reported from

- Norway (Wennervirta 1969; Bugge 1980; Henriksen 1983; Often 1985; Olsen and Nilsen 1985),

- Sweden (Nilsson 1985), and

- the Soviet Union (Väyrynen 1938; Kulikov et al. 1980; Zagorodny 1980; Rybakov and Lobach-Zhuchenko 1981; Pozhilenko 1984).

\section{Palaeogeographic outline ( $>1.9$ Ga)}

The Precambrian bedrock in Finland (Fig. 1) consists of an Archaean basement complex and an early Proterozoic Svecokarelian fold belt enveloping rapakivi granites and underlying minor middle Proterozoic Jotnian sedimentary rocks (Simonen 1980). The Raahe-Ladoga tectonic belt separates the Archaean domain from the Svecofennian crustal segment (H. Huhma 1986), where geologic events prior to $1.9 \mathrm{Ga}$ are unknown.

The Archaean basement is largely a granitoid complex of gneisses dated at 3.1-2.8 Ga (Simonen 1980; Kröner et al. 1981; Luukkonen and Lukkarinen 1986; Paavola 1986; H. Huhma 1987), but material as old as $3.2 \mathrm{Ga}$ has been recognized from the detritus in Archaean metasediments (H.Huhma 1987). Nd-isotopic data on the rare protolith indicate derivation from the mantle at least $3.5 \mathrm{Ga}$ ago (Jahn et al. 1984). The gneissose granitoids are similar in age determinations and lithology to the Saamian gneisses described by Salop (1983, pp. 22-72) from the USSR, where the geochronological event at 3.1-3.0 Ga is considered to be cratonization (Musatov et al. 1984). The complex was polycyclically intruded by different granitoids of 2.8-2.4 Ga age (Simonen 1980; Martin et al. 1983; Martin and Querre 1984; Luukkonen and Lukkarinen 1986) and subjected to polyphase deformation and metamorphism (Kröner et al. 1981; Luukkonen 1985; Paavola 1986). Hence, the granitoid basement, which is understood as the Pre-Svecokarelian granite-gneiss complex (Simonen 1980) with a Saamian body of unknown extent, is complicated in structure. The post-Saamian granitoids, some of which are genetically linked to adjacent metavolcanics (Taipale 1979; Martin 1987), occur at the borders of the Archaean greenstone belts (Gaál et al. 1978; Barbey and Martin 1987). Therefore, the ?preKuhmoan or Tuntsan argillaceous gneisses are sometimes difficult to identify (Luukkonen and Lukkarinen 1986; cf. Saverikko 1987 vs. Juopperi and Veki 1988).

In eastern Finland, the Saamian gneisses surround distinct synforms between granitoid diapirs in the Kuhmo, Suomussalmi and Ilomantsi greenstone areas (Gaál et al. 1978; Luukkonen and Lukkarinen 1986). Deposition of the Kuhmoan supergroup (Simonen 1971; Luukkonen and Lukkarinen 1986), at 3.0-2.5 Ga (Taipale et al. 1983), began in a continental environment but advanced in oceanic rifting so that two vol- 

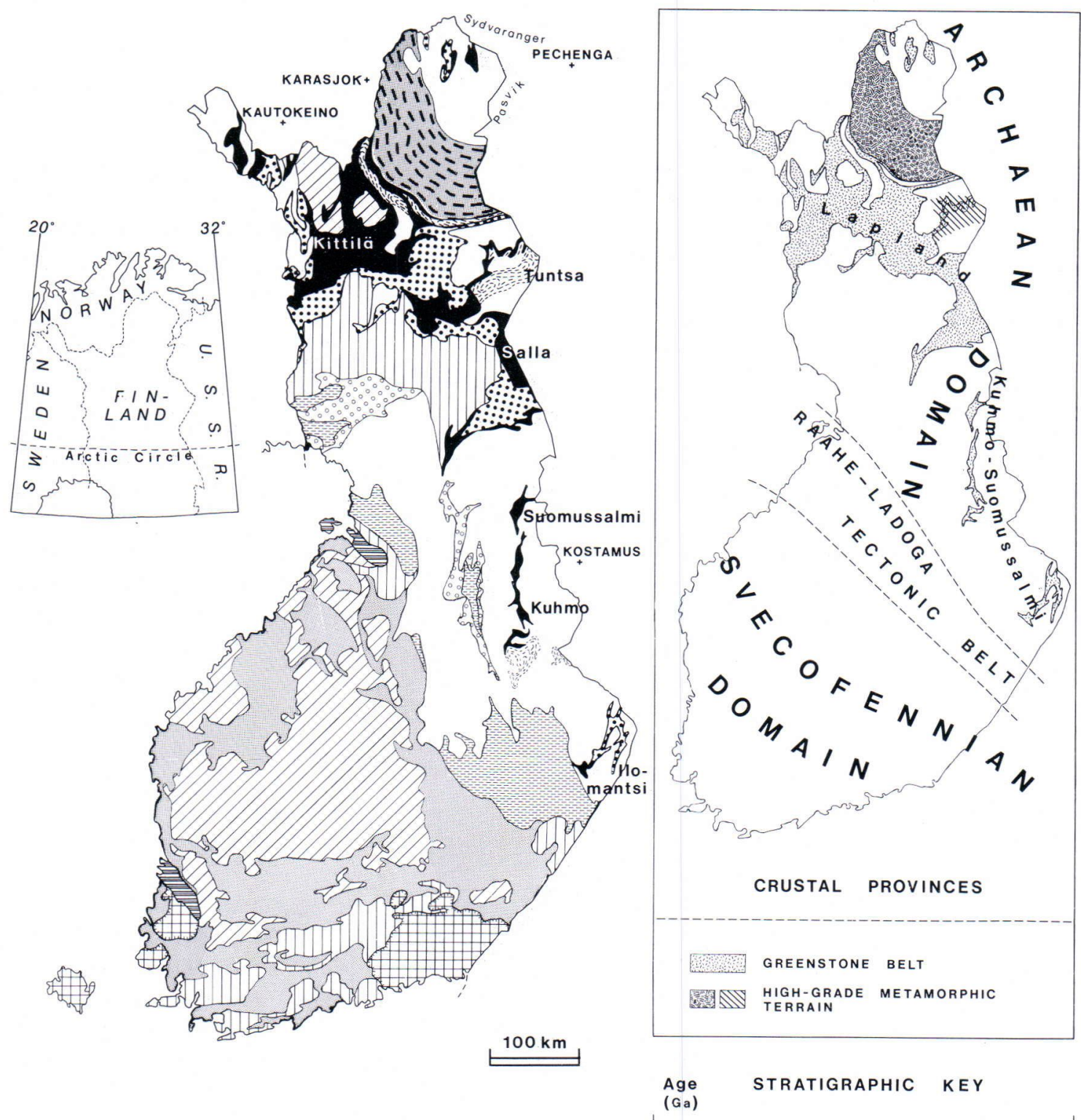

\section{ARCHAEAN}

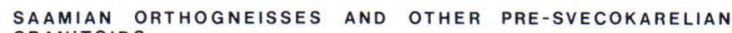
GRANITOIDS

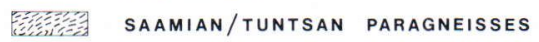

\section{1}

KuHMoan or lapponian: 1. greenstone area, 2. metaSEDIMENTS

E= GRANULITES

\section{PROTEROZOIC}

\section{KARELIAN ARENACEOUS ROCKS}

KaLEVAN ARGillaceous ROCKS

BOTHNIAN VOLCANIC-SEDIMENTARY SEQUENCE

JOTNIAN SEDIMENTARY ROCKS

GRANODIORITE AND QUARTZ DIORITE

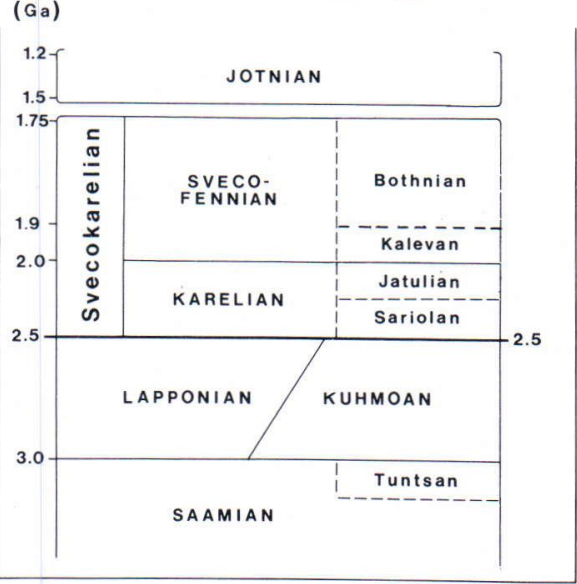

GRANITE

HIII RAPAKIVI GRANITE

Fig. 1. Outline of the Finnish Precambrian, simplified after Simonen (1980); Taipale et al: (1983); H. Huhma (1986); Luukkonen and Lukkarinen (1986); Gaál and Gorbatschev (1987) and Saverikko (1987). 
canic complexes are now separated by terrigenous metasediments of shallow-water nature (Martin et al. 1984; Barbey and Martin 1987). The terrigenous strata of continental to marine sediments (Lavikainen 1977) may also be intercalated in a volcanic sequence (Tuukki et al. 1987) in the Ilomantsi area.

In northern Finland, the Lapponian supergroup (Sederholm 1932; Silvennoinen et al. 1980) includes metavolcanics in the Salla-Jauratsi and Kittilä greenstone areas (Gaál et al. 1978), and forms the Lapland greenstone belt. Terrigenous rocks with basal arkoses abound in many places (Lehtonen et al. 1985a; b; Saverikko 1987), and the cratonic to riftal stratification at $3.0-2.5 \mathrm{Ga}$ started in a continental environment and continued with advancing mantle-activated rifting (Saverikko 1987).

A paired metamorphic pattern in northern Finland is seen in the Tuntsa-Savukoski ultrametamorphic zone (Mikkola 1941, Gaál et al. 1978) and, much more obviously, in the adjacent granulitic complex of 2.8-2.5 Ga age (Meriläinen 1976) and Lapponian parentage (Saverikko 1987). Granulites of komatiitic affinity are encountered in the USSR (Suslova 1976). One or more Svecofennian metavolcanics (BernardGriffiths et al. 1984) extruded through the major thrust plane of the granulitic arc (Barbey et al. 1984), giving rise to the debate about the Proterozoic age of the granulites (Barbey and Martin 1987).

There are quartzites at the base of the granulitic complex (Meriläinen 1976), which is regarded as continental trench fill in origin (Barbey et al. 1980; Saverikko 1987). Its deposition was characterized by continental volcanism and gravity-flow sedimentary processes within or close to the shallow-water platform (Barbey et al. 1984; Barbey and Martin 1987).

The Archaean craton, reconsolidated at $2.6 \mathrm{Ga}$ (Silvennoinen 1985), is overlapped by the Svecokarelian sequence, with the Karelian platformal rocks lying on the craton and adjacent to the younger Svecofennian geosynclinal strata
(Simonen 1980). The Karelian supergroup, younger than $2.5 \mathrm{Ga}$, was traditionally subdivided into the Sariolan, Jatulian and Kalevan successions (see Meriläinen 1980; Simonen 1980). However, Gaál and Gorbatschev (1987) abandoned the historical-geographical linkage and included the Kalevan miogeosynclinal rocks in the Svecofennian geosynclinal supergroup of $2.0-1.75 \mathrm{Ga}$ age.

Deposits of the Sariolan conglomerate-arkosite-argillite-greenstone suite (see Luukkonen and Lukkarinen 1986) are riftal, glacial and/or stable-platformal in character (e.g. Pekkarinen 1979; Marmo and Ojakangas 1984). The Jatulian quartzite-dominant deposits formed an extensive epicontinental sheet (Ojakangas 1965) which underlies the Marine-Jatulian dolomite-slateblack-slate suite (Meriläinen 1980), demonstrating transgression before deposition of the Kalevan greywacky slates.

\section{Archaean stratigraphic correlations}

Some comments are called for regarding the discrepancy in the chronostratigraphy of the Archaean greenstone belts. The Kuhmo-Suomussalmi greenstone belt has been dated at 3.0-2.5 Ga (Taipale et al. 1983), but ages of $2.65-2.5$ Ga have also been suggested in spite of komatiitic relics older than $2.86 \mathrm{Ga}$ (Martin et al. 1984; Martin 1987). Mr. K. Taipale thinks, in accordance with Page (1978), that the age discrepancy could be due to systematic analytical differences caused by marked rejuvenation of the $\mathrm{Rb}-\mathrm{Sr}$ whole rock ages in comparison with the U-Pb zircon ages (Piirainen 1985). That is agreed by Vaasjoki (1988) preferring the zircon-based chronology as put forward by Luukkonen and Lukkarinen (1986), who, in their part, suggest an age of $2.9-2.5 \mathrm{Ga}$.

The chronostratigraphy of the Lapland greenstone belt is also controversially delineated: Silvennoinen et al. (1980) considered the span to be 
3.1-2.6 Ga, whereas Silvennoinen (1985) maintained that Lapponian deposition started not until $2.6 \mathrm{Ga}$ ago and continued into the Early Proterozoic. The time interval of 3.0-2.5 Ga, concluded and discussed by Saverikko (1987), may be understood as the maximum span. The smouldering opinion about Proterozoic origin of the Lapponian rocks will be deemed worthy of acceptance when carrying arguments and amendments against those in Figure 2.

The Lapland greenstone belt with pyroclastic komatiites covers the Kautokeino and Karasjok areas in Norway (Fig. 3). Nevertheless, Siedlecka et al. (1985) consider these rocks early Proterozoic as a result of a $\mathrm{Sm}-\mathrm{Nd}$ dating of 2.08 $\mathrm{Ga}$ from the upper Lapponian komatiites (Krill et al. 1985) at Karasjok where a quartzite is cut by an albite-rock dyke of $2.72 \mathrm{Ga}$ age (Meriläinen 1976); dating attempted at Kautokeino was not successful (Krill et al. 1985). Meriläinen (1976) and Bernard-Griffiths et al. (1984) have documented a tectono-metamorphic convulsion at $2.15-1.90 \mathrm{Ga}$ or $2.0-1.9 \mathrm{Ga}$ in the surround- ings. As a speculation, assimilation of a sialic crust may modify the isotopic pattern of hightemperature lavas and rendered whole-rock Sm$\mathrm{Nd}$ dating of Archaean komatiites highly suspect (Huppert and Sparks 1985; Cattell 1987).

The Kuhmoan and, in the USSR, the Lopian sequences have been stratigraphically likened to each other (e.g. Salop 1983, p. 74). However, Salop (1983, p. 136) associated the Lapponian with the Sumian of post-Lopian origin, and Muradymov et al. (1988) consider the Lapponian equal to the Lopian. As noted above, the Kuhmoan and Lapponian sequences have a strong mutual resemblance in age and lithostratigraphy, whereas the Lopian appears to be correlative to the lower-middle Lapponian/Kuhmoan succession (Fig. 4). The Archaean greenstone-belt associations in Finland are thus comparable to the Lopian-Sumian supracrustal complex. That is why the Archaean greenstone-belt genesis is proposed to be called the Cwenan diastrophism (Saverikko 1987) instead of the Lopian orogeny (e.g. Gaál and Gorbatschev 1987).

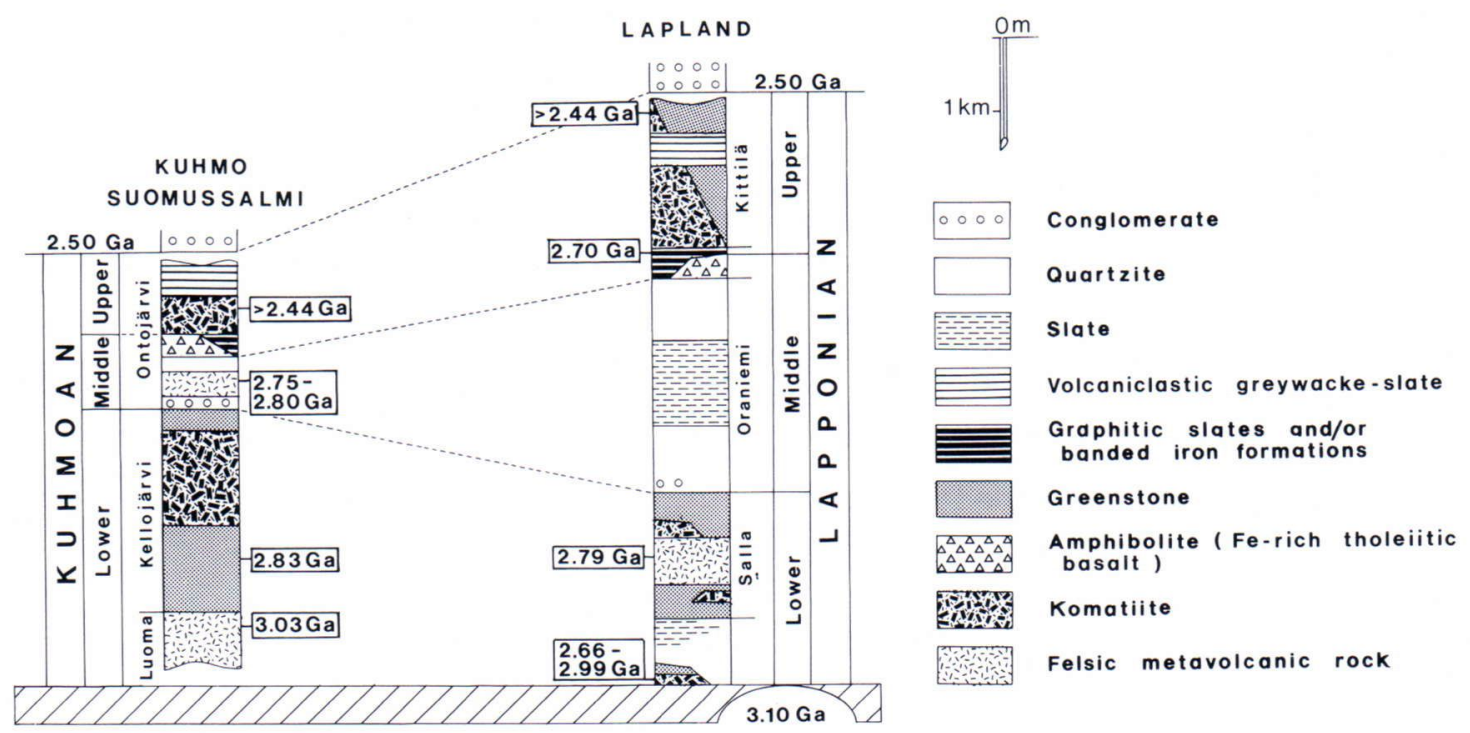

Fig. 2. Stratigraphic similarity between the schematic composite stratotypes in Lapland (Saverikko 1987) and the KuhmoSuomussalmi area (Taipale et al. 1983; Piirainen 1985). The Kuhmoan supergroup is tentatively subdivided into lower, middle and upper Kuhmoan groups. The lower time limit is obscure, because the age determinations of 3.03 Ga (Kuhmo) and 2.99 $\mathrm{Ga}$ (Lapland) are common lead ages from galenas (M. Vaasjoki, oral commun. 1988). 


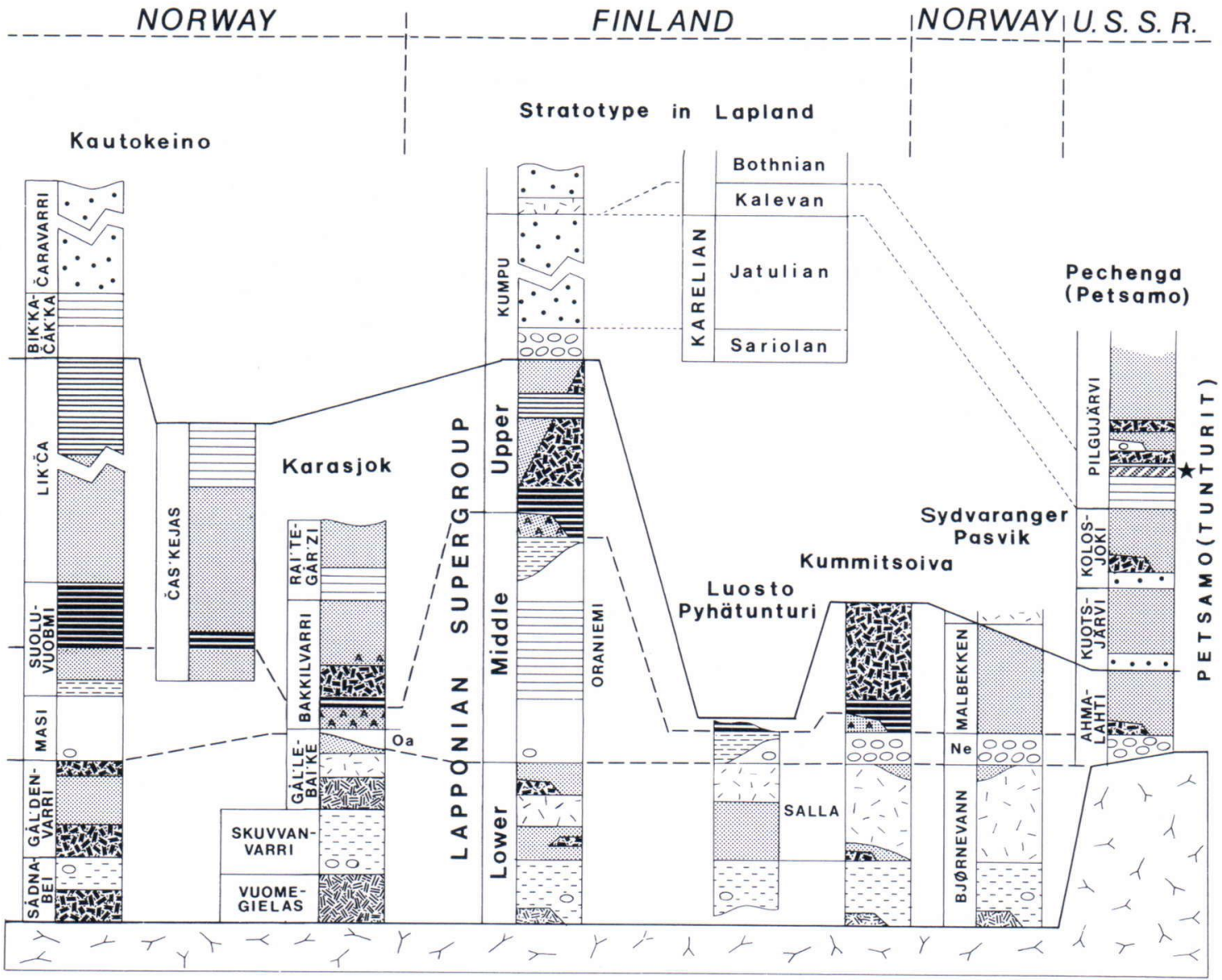

Oa OALGEJÄKKA

Ne NEVERSKRUKK

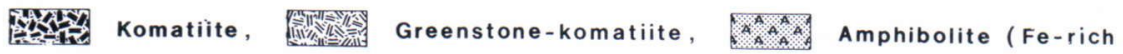

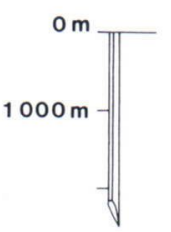

tholeitic basalt), A Felsic or B) mafic metavolcanic, caniclastic greywacke-slate, 宑 Graphitic slate/schist zone (incl. albite felsite, carbonate, jaspilite etc.), Slate/schist, Metasiltstone,

Quartzite-carbonate-schist, $\square$ Quartzite,

$\because \because$ Conglomerate-metasandstone-slate,

and $\mathrm{Ni}-\mathrm{Cu}$ deposits, $\quad<$ Orthogneisses and paragneisses.

Fig. 3. Apparent lithostratigraphic relation between the greenstone-belt associations stratified in Finnish-Norwegian Lapland and the western Kola Peninsula (USSR). The sequences in Pechenga and Sydvaranger-Pasvik are included in the Pechenga greenstone belt. The ?Karelian metasediments are characterized by brown to violet metasandstones at Kautokeino (Reitan 1960, Siedlecka et al. 1985) and Pechenga (Zagorodny 1980), which are distinctive members of the Kumpu association, too (Mikkola 1941). Zagorodny (1980) and Salop (1983, p. 172) refer the Kuotsjärvi-Kolosjoki rock suite to the Jatulian, and thus the lower Pilgujärvi greywacky slates may be correlative with those of the Kalevan; there are also volcaniclastic komatiites (see Väyrynen 1938, pp. 144-148) in the Pilgujärvi succession. The composite stratotypes are as follows: Kautokeino (Solli 1983; Olsen and Nilsen 1985; Siedlecka et al. 1985), Karasjok (Skålvoll 1964; Henriksen 1983; Often 1985; Siedlecka et al. 1985), Finnish Lapland (Saverikko 1987), Luosto-Pyhätunturi (Haimi 1977), Kummitsoiva (Saverikko and Manninen 1981), Sydvaranger-Pasvik (Bugge 1980; Siedlecka et al. 1985), and Pechenga (Zagorodny 1980). The Petsamotunturit supracrustal complex (Sederholm 1930) is called the Petsamo or Pechenga group or supergroup (Salop 1983, p. 172; Siedlecka et al. 1985). 


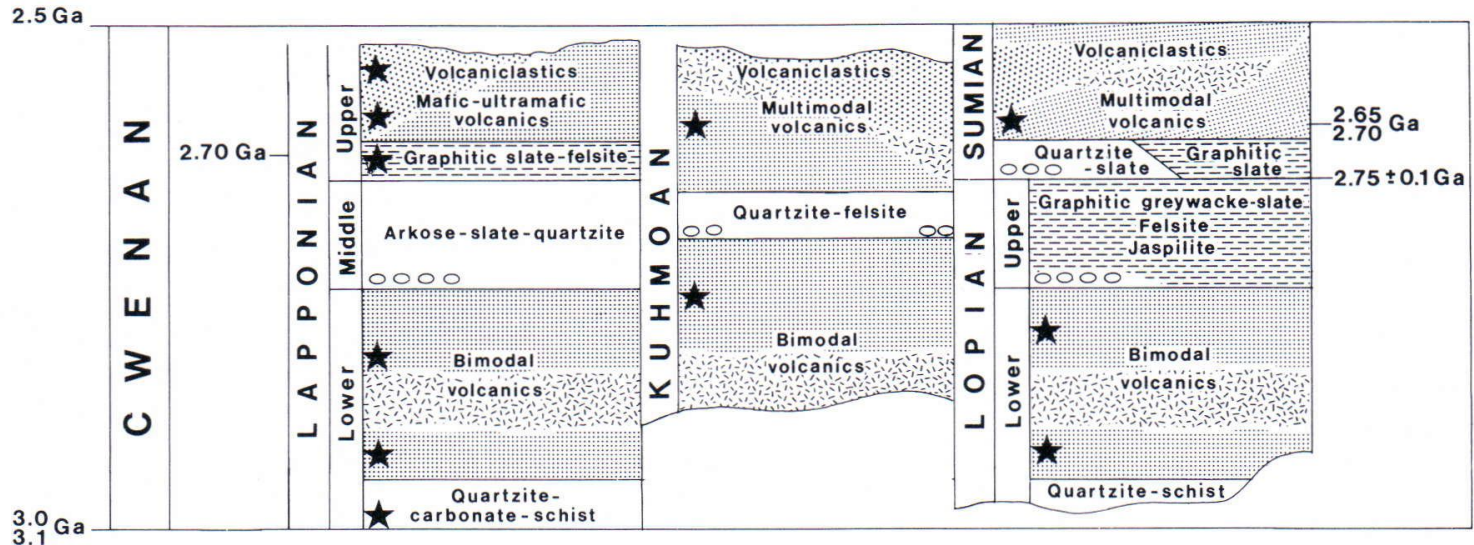

$\star$ Komatiitic eruptions, 000 Conglomerate.

Fig. 4. Late Archaean greenstone-belt genesis in the Fennoscandian Shield is here called the Cwenan diastrophism or orogenic megacycle (Saverikko 1987). Its depositional history is recorded in Lapponian, Kuhmoan, and Lopian-Sumian (USSR) sequences capped by Sariolan, i.e. lower Karelian, deposits. The Lopian characteristic assemblages are compiled after Rybakov and Lobach-Zhuchenko (1981), Salop (1983, pp. 110-111) and Lobach-Zhuchenko et al. (1986), and those of the Sumian after Gaskelberg et al. (1986) and Zagorodny et al. (1986). The Lopian deposition may have occurred at $3.0 \pm 0.1 \mathrm{Ga}$ to $2.75 \pm 0.1 \mathrm{Ga}$ (Kulikov et al. 1984; Lobach-Zhuchenko et al. 1986) rather than at 3.5 Ga to 3.0 Ga (Gorbunov et al. 1985a). The Sumian komatiitic eruptions 2.7-2.65 Ga ago (Lobach-Zhuchenko and Levchenkov 1986) may have been coeval with upper Lapponian komatiitic explosive volcanism.

\section{Komatiitic exposures}

The komatiitic rocks in the Finnish Archaean greenstone belts are divided into three compositional families, the limits of $\mathrm{MgO}$ content (anhydrous basis) being at ca. 30, 18 and 9 wt $\%$ (Sarapää 1980; Auvray et al. 1982; Saverikko 1985): the members are peridotitic komatiites $(\mathrm{MgO}>30 \mathrm{wt} \%)$, pyroxene peridotitic komatiites ( $\mathrm{MgO} 30-18 \mathrm{wt} \%$ ) and komatiitic basalts (MgO 18-9 wt\%) (Pihlaja and Manninen 1988). All these members include pyroclastics and can thus be understood as distinct rock species. This usage differs slightly from that recommended by Arndt and Nisbet (1982), but it is petrographically well definable in Finland.

The peridotitic komatiite is commonly a coarse-grained, olivine or pyroxene-dominant cumulate with intrusive or random volcanic field characteristics; it rarely forms pyroclastics. The pyroxene peridotitic komatiite occurs as tremo- lite-chlorite rock carbonated to varying degrees; it is characterized by pyroclastics and fragmentary lava flows with or without basal cumulates. The komatiitic basalt, now an actinolite-hornblende rock with disseminated plagioclase, consists of compact lavas and infrequent ejecta. (Kallio et al. 1980; Auvray et al. 1982; Saverikko 1983; 1985; Pihlaja and Manninen 1988).

The volcaniclastic terminology used in this essay accords with that discussed by Fisher and Schmincke (1984, pp. 89-96).

\section{Archaean volcaniclastic komatiites}

The Kuhmoan and Lapponian sequences contain komatiites in the lower and upper volcanicdominant groups (see Fig. 2), but the pyroclastic variants are lacking in the Ilomantsi area, where the volcanic supercomplexes are separated by a conglomerate-greywacke-slate-jaspilite 
association and an Fe-rich tholeiitic basalt (see Tuukki et al. 1987).

Kuhmo-Suomussalmi greenstone belt

The komatiitic rocks can be traced in narrow exposures of two distinct interlayers, the lower of which contains a few volcaniclastics in the Siivikkovaara complex (Fig. 5). According to Hanski (1980), the Siivikkovaara komatiite complex is made up of pyroxene peridotitic komatiite in the lower part, komatiitic basalt in the upper part and an intertongued transitional zone. In the uppermost part, fine-grained volcaniclastics of mafic to ultramafic mineral composition are separated from the lavas by an early Proterozoic serpentinite massif (Hanski 1980; 1986).

The pyroxene peridotitic komatiite is present in massive to pillowed lavas (Hanski 1980). Several flows exhibit clinopyroxene spinifextexture; that zone of the pyroxene-plagioclaseolivine assemblage is prevailingly mafic in chemical composition (Hanski 1980). The flow-brecciated lavas sometimes pass laterally to autoclastic deposits in which angular to subangular, cored fragments $(\varnothing 0.1-10 \mathrm{~cm})$ are embedded in tuff (Hanski 1980: Fig. 21). One minor tuff breccia of mixed composition contains individual ultramafic blocks $(\varnothing<1.2 \mathrm{~m})$ in mafic tuffaceous material (Hanski 1980). The overlying komatiitic basalt contains abundant lava pillows, the variolitic pillows being frequently brecciated (Hanski 1980).

In palaeogeography, the komatiitic volcanism followed mafic eruptions which occurred in moderately deep water (Hanski 1980) and produced abundant exhalative ferruginous precipitates (Tuokko 1979). In the pyroxene peridotitic komatiite, the few pillow lavas between and adjacent to the massive flows indicate a stretch of water and, therefore, the minor volcaniclastics with cored fragments may be products of steam eruptions. The absence of vesicles postulates a volatile-poor magma, if the gases were not escaped. Similarly, mafic fine ejecta of mixed blocky tuff can be ascribed to the bursting of a lava differentiated before or during the flow. If a variolitic texture of amygdale-free pillows associated with shattering manifests a deepwater environment (Furnes 1973), the pillowbrecciated flows of komatiitic basalt indicate submergence. The komatiitic lava field was exposed and fed mafic to ultramafic volcaniclastics before regional emergence which preceded felsic volcanism (Hanski 1980) and shallow-water sedimentation (Barbey and Martin 1987).

\section{Lapland greenstone belt}

Volcaniclastic komatiites are known from three volcanic cycles. Those of the lower Lapponian are exposed in initial komatiitic greenstones at the base and in a few occurrences within the Salla greenstone complex, but the isolated upper Lapponian komatiite complexes are manifestations of marked explosive volcanism (Fig. 6).

The initial komatiitic greenstones underlie a cratonic quartzite-carbonate-schist association. At Möykkelmä (see Fig. 8), the best known volcanic pile is mainly composed of volcaniclastics of pyroxene peridotitic komatiite or komatiitic basalt, intercalated with and capped by tholeiitic greenstones of andesitic to basaltic composition; the REE patterns indicate sialic contamination (Räsänen et al. 1986). The basal layer of tuffaceous Möykkelmä komatiite envelops granitoid fragments, but with an increasing amount of coarse ejecta the lapilli tuff passes to agglomerate or blocky tuff with coarse accessory ejecta (see Saverikko 1987). At Kurittukoski, some peridotitic komatiites without any primary structures or textures are associated with or penetrated these metavolcanics (Pihlaja and Manninen 1988).

The exposure at Kivivuotsonselkä (Räsänen $1983 ; 1984)$ is composed of olivine basal-cumulate and fine-grained lava but shows olivine spinifex-textures as well; flow-top breccias imply incipient volcanic fragmentation. 
At Nuolusvaara, in the Tuntsa-Savukoski ultrametamorphic terrain, the elongated, narrow bodies of pyroxene peridotitic komatiite constitute a fine-grained and strongly foliated rock except in a few massive portions (Veki 1985). The schistose rock was originally fine ejecta if the distinct and lineated amphibole aggregates (Veki 1985) are coarse-grained pyroclasts, but strongly foliated margin of the vesicular lava flow if the aggregates are deformed amygdales. The komatiite is covered by quartz and/or plagioclase-banded greenstone of mixed to epiclastic nature inferred by Veki (1985).

The first Lapponian volcanism generated komatiitic and tholeiitic lavas in connection with explosions of unknown origin. The absence of subaqueous features is suggestive of subaerial eruptions, as is confirmed by unwashed palaeoresidue of the Saamian basement (see Mikkola 1941; Räsänen 1977), which supplied gneiss blocks at Möykkelmä. Despite the poor exposure these metavolcanics protrude from the cratonic metasediments in northern Norway, too (see Fig. 3), where they are known as Vuomegielas greenstones with komatiitic members (Siedlecka 1985; Often 1985) and as Sådnabei komatiitic basalt of lava-tuff association with an increasing amount of detritus (Olsen and Nilsen 1985).

The Salla greenstone complex of bimodal volcanics overlies the cratonic metasediments and encloses a few komatiites within mafic greenstones above and below a felsic interlayer (Saverikko 1987).

These ultramafics are at their most common in the Sokli area. However, their division revised here after Virransalo (1985) and Kauniskangas (1987) into lower and upper komatiite assemblages is not unambiguous. Those at the inferred lower level are called Kuttusvaara komatiites which are exposed in differentiated flows of peridotitic komatiite to komatiitic basalt (Virransalo 1985). In addition to the olivine cumulate there is an olivine spinifex-textured rock (Kauniskangas 1987), and in places the olivineserpentine rock exhibits structures resembling flow breccias or even block lavas, which were, however, attributed to spheroidal weathering (Kauniskangas 1987). The apparent flow breccias occur in the flow margins (Virransalo 1985), grading in places into volcaniclastic breccia with fragments $2-20 \mathrm{~cm}$ in diameter (Kauniskangas 1987).

At Purkkivaara, a peridotitic komatiite is associated with mafic tuffs (Manninen 1981), and at Aatsinginhauta, a lithic-vitric tuff, pyroxene peridotitic komatiite in mineral composition (Saverikko 1987), occurs together with mafic tuffs in slumped strata (Saverikko and Manninen 1981).

The upper komatiites, or Jänesselkä komatiites, are rocks of ultramafic to komatiitic basalt (Virransalo 1985) that show differentiated layered structures (Kauniskangas 1987) but overlie terrigenous metasediments; intervolcanic weathering was concluded by Saverikko (1987) to be also elsewhere.

The Salla greenstone complex of plateau-basalt origin extruded predominantly in a terrestrial environment (Saverikko 1987), with the komatiitic eruptions as further ingredients. A considerable amount of glassy ejecta in the lithic-vitric tuff, which has been unearthed at only one site, may be weak evidence of viscous magma (see Fisher and Schmincke 1984, p. 76). At any rate, the subordinate ultramafic material appears to have squeezed out largely as crystal mush and to have differentiated gravitationally before bursting when it came into contact with water. Furthermore, the Gål'denvarri and Gål'lebai'ke greenstone complexes in northern Norway, which may be comparable to the Salla complex (see Fig. 3), are predominantly composed of fragmented komatiites such as those present in the form of pillow-breccia; shallow-water to subaerial palaeoenvironments are demonstrated by Often (1985). The fragmentation of all these komatiites is thus attributed to water-indicating phreatic or phreatomagmatic explosions.

The main pyroclastic komatiite zone is conspicuous in the large explosive centres at Sattasvaara, 
A

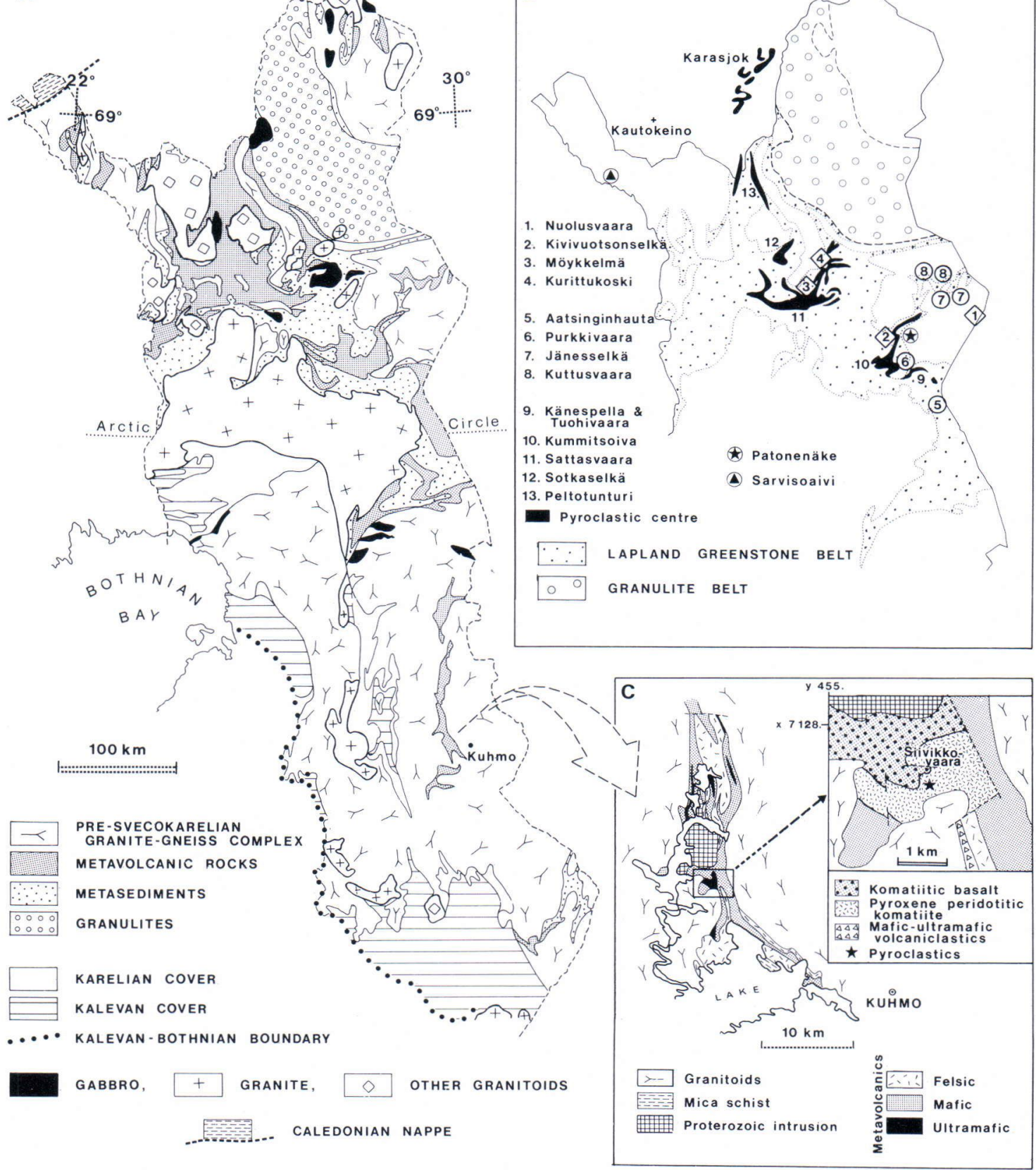

Fig. 5. A. Lithologic setting of the Archaean domain in Finland. - B. Komatiite exposures from the Lapland greenstone belt: numbers $1-4$ refer to the initial volcanics; $5-8$ to those within the Salla bimodal volcanics of the lower Lapponian; and $9-13$ to the pyroclastic centres that form the upper Lapponian pyroclastic komatiite zone. The stratigraphic position of exposures at Patonenäke and Sarvisoaivi are not known. - C. Exceptional volcaniclastic komatiites of the KuhmoSuomussalmi greenstone belt are concentrated in the Siivikkovaara complex (Hanski 1980; Taipale et al. 1983). 


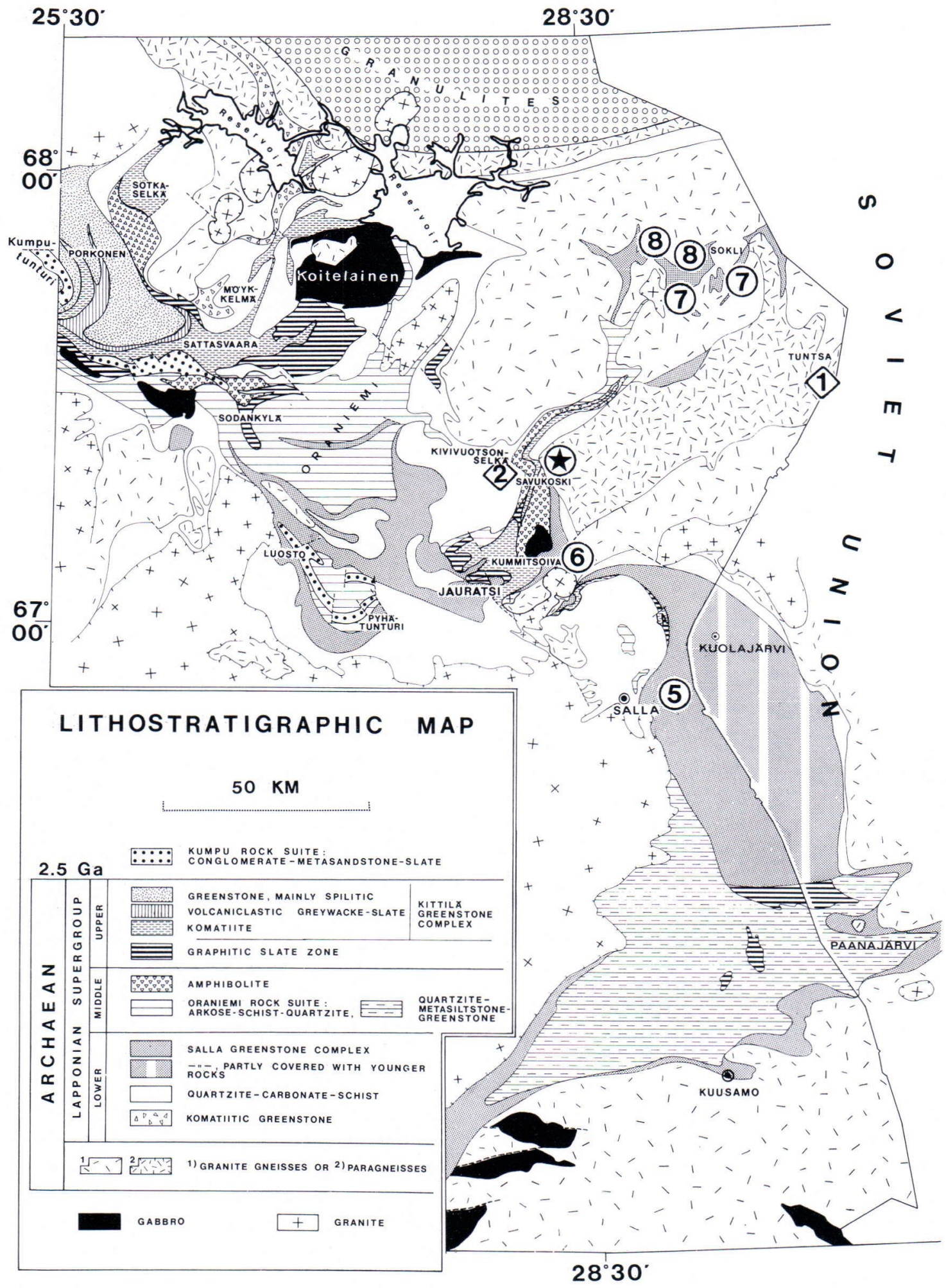

150 Komatiite exposures mentioned in Figure 5

Fig. 6. Geological sketch map of the eastern part of the Lapland greenstone belt (Saverikko 1987); after Simonen (1980) and Piirainen (1985) for the Tuntsan paragneisses. 


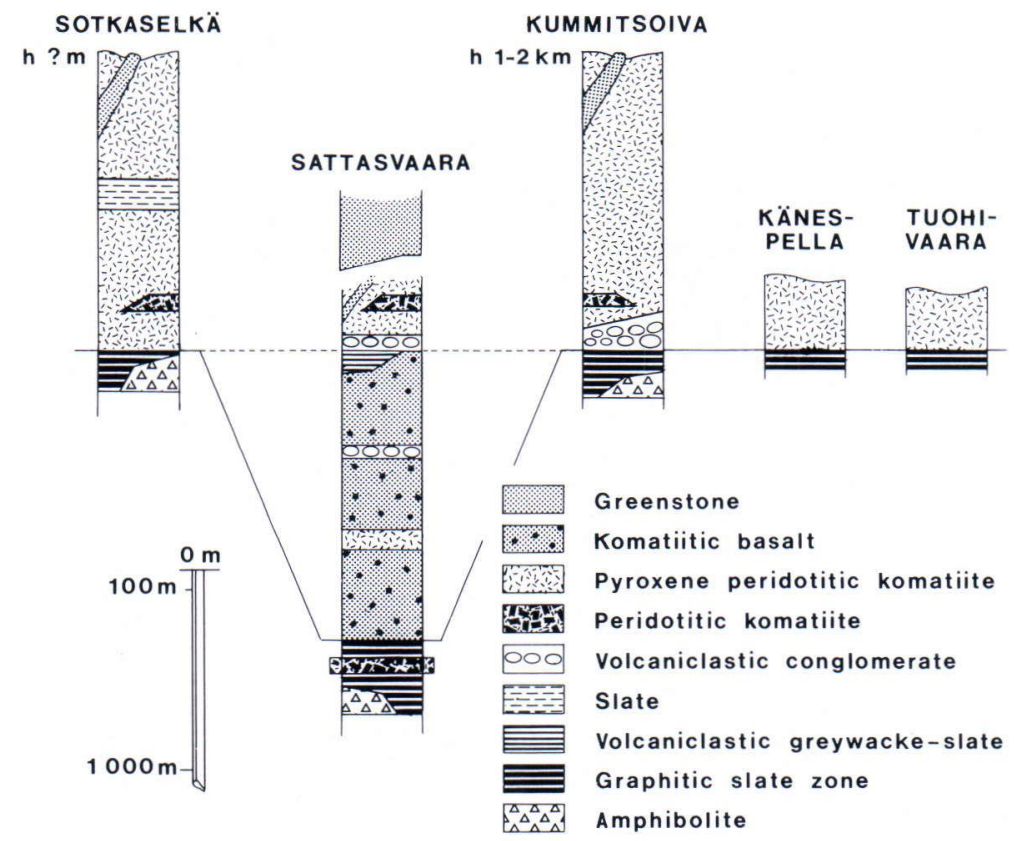

Fig. 7. Lithostratigraphic correlation of the upper Lapponian komatiite complexes at Sotkaselkä (Kallio et al. 1980; Kallio 1980), Sattasvaara (Saverikko 1985) and Kummitsoiva with its satellites (Saverikko 1983).

Kummitsoiva and Sotkaselkä, all of which overlie a heterogeneous slate suite characterized by graphite and other euxinic-exhalative precipitates (Saverikko 1987). This noteworthy part of upper Lapponian volcanism is documented most thoroughly in the Sattasvaara complex (Fig. 7).

The explosive nature of the Sattasvaara komatiite complex (Fig. 8) increases upwards in relation to magmatic composition. Thus the komatiitic basalt is mainly composed of massive to pillowed lavas but the pyroxene peridotitic komatiite is fragmentary throughout; the subordinate flows are block lavas (Saverikko 1985). Pyroxene peridotitic komatiites predominate in the east (Pihlaja and Manninen 1988), whereas komatiitic basalt (Kallio et al. 1980) intertongued by Kittilä greenstones (Paakkola 1971; Rastas 1980 ) is the only component in the west. The distinctive constituents of this complex are several peridotitic komatiite plugs and terminal flows associated with the upper layer of pyroxene perido- titic komatiite; the peridotitic komatiite occurs in fact as sheets within the graphitic slate zone beneath the komatiite complex (Saverikko 1985).

The komatiitic basalt ejecta are present in individual lapilli around a spatter cone or in pyroclastic breccias along with a volcaniclastic conglomerate between the pillow-lava piles (Saverikko 1985); Kallio et al. (1980) described hyaloclastics within the pillow-breccia. The essential-accessory ejecta of ash to bombs/blocks are lithic and contain augitic crystals; vitric ejecta are very rare (Saverikko 1985).

The pyroclastics of pyroxene peridotitic komatiite are lapillistone in which lapilli tuffs or agglomerates seldom form deposits, not even immature ones (Saverikko 1985, Pihlaja and Manninen 1988). Cored lapilli or lapilli with a chilled margin are concentrated in and around vents, the best instance of which is the cinder cone in Sattasvaara hill (Saverikko 1985). The lithic-vitric ejecta of bomb to ash size range include a few 

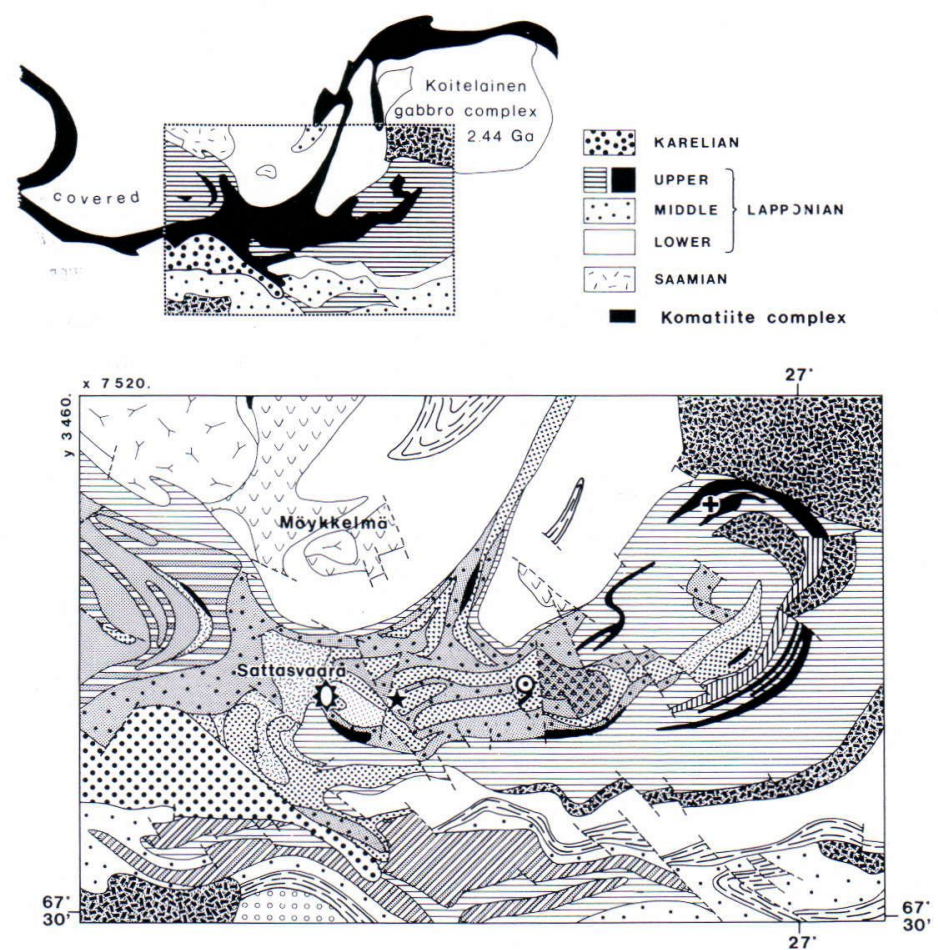

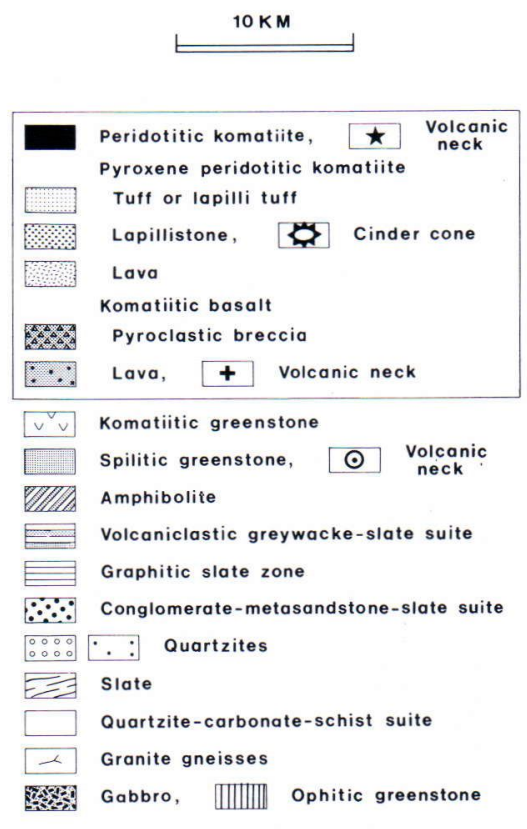

Fig. 8. Lithologic features and environment of the Sattasvaara komatiite complex and the Möykkelmä komatiitic greenstone (Saverikko et al. 1983; Saverikko 1985).

tuff deposits of crystal (olivine, clinopyroxene) ash; the essential ejecta are mixed with minor accessory ejecta and several accidental pyroclasts (Saverikko 1985). The weakly vesicular lavas, too, are distinguished by the volcanic glass present as droplets or, in basal cumulates, as larger vitrophyric blisters (Saverikko 1985).

The peridotitic komatiite seems in fact to be a completely accumulative rock: the cumulus olivine crystals are surrounded by augite and hyperstene, and the layered structure of the sheets with signs of lava piles is due to the variation in olivine abundance (Saverikko 1985). Agglutinatic structure is rare within these coarse-grained sheets (Saverikko 1985). The small exposures within the Sattasvaara complex proper are mostly structureless, but there is one cumulate flow with a fragmented, thin crust of pyroxene peridotitic komatiite (Saverikko 1985).
Komatiitic volcanism was controlled by faultblock movements, and depositional conditions varied from subaerial to subaqueous in a coastal environment; the eruption fissures are visible in lava dykes and chains of terminal vents (Saverikko 1985; Pihlaja and Manninen 1988). The komatiitic basalt discharged in Hawaiian-type eruptions, whereas the pyroxene peridotitic komatiite was produced by Strombolian-type eruptions, the both being accompanied by small phreatic explosions (Saverikko 1985). These eruptive periods were separated by erosional periods in the course of which the volcaniclastic conglomerate-greywacke-slate association was laid down (Saverikko 1985; 1987).

The Kummitsoiva komatiite complex is a central-vent palaeovolcano with eruption fissures at the margin and associated or separate satellites in the environment (Fig. 9). The pyroxene perido- 

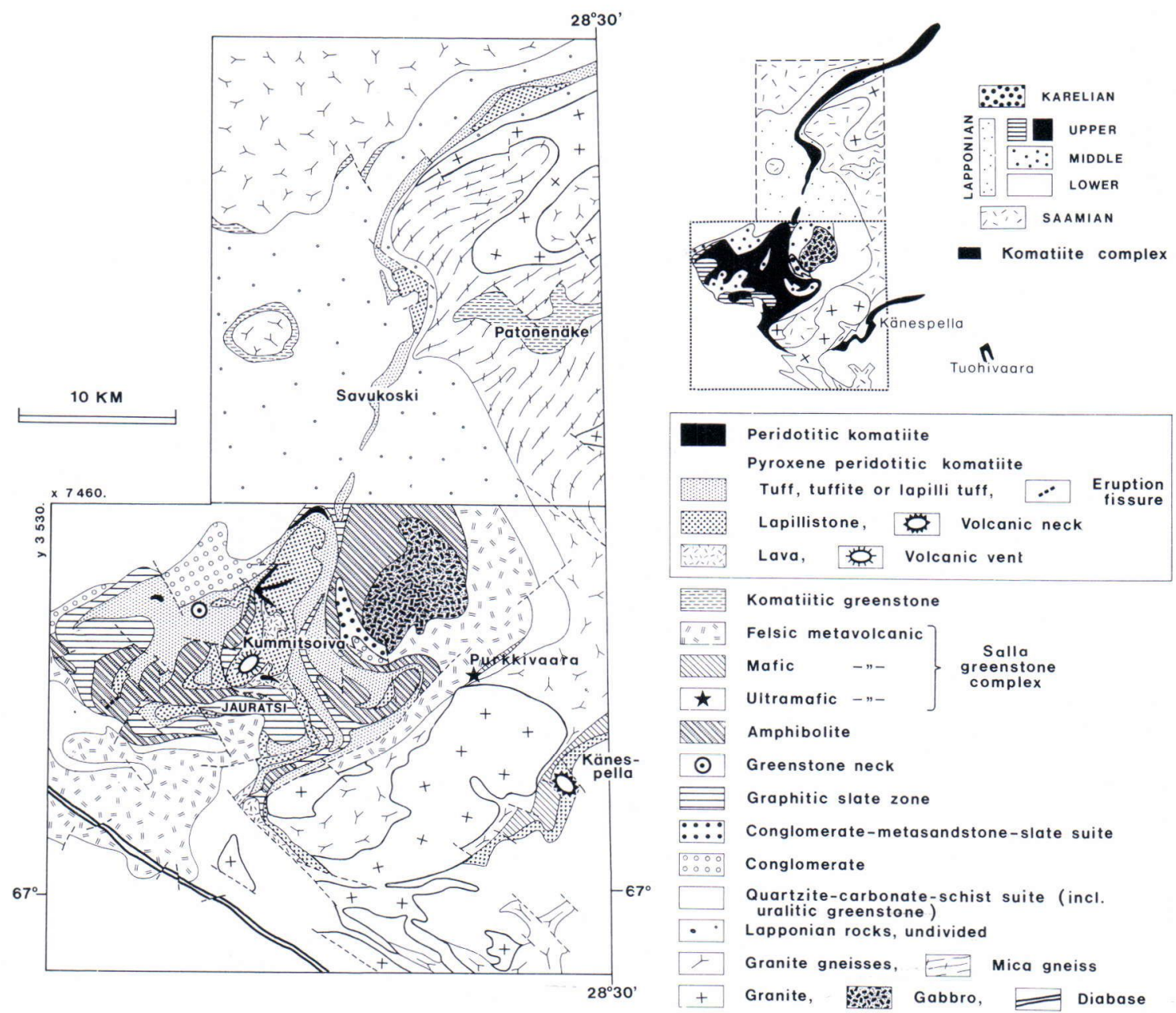

Fig. 9. Lithologic features and environment of the Kummitsoiva komatiite complex and its satellites (Saverikko 1983; Saverikko et al. 1983). The geological setting in the Savukoski map sheet is simplified after Juopperi (1986), and does not include the Lapponian subdivision; the komatiitic greenstones in the west are part of the exposures at Kivivuotsonselkä; those at Patonenäke are regarded here as lower Lapponian, even though they lie within (upon?) the Tuntsa province.

titic komatiite complex overlies a depressional fill of volcaniclastic conglomerate and contains several intercalations of peridotitic komatiite.

The autobrecciated lavas and pyroclastics are intermingled in a zonal manner: the amount of pyroclastics, particularly tuffaceous rocks, increases with distance from the centre while the block lavas grade laterally into poorly sorted ejecta of disordered stratification. The essentialaccessory ejecta mixed with the rare accidental pyroclasts are mainly lapillistone or lapilli tuff. Spatters are very rare except for the scorias lying near and on the central vent. Pyroclastic breccias also appear to be uncommon. Reworking is recognizable in places, and the volcanic fines in the distal zone are komatiitic debris and lithicvitric tuffs with olivine and pyroxene crystals. A palaeoresidue of one massive flow is also encountered. In the distal zone the tuffaceous rocks are stratified into massive to laminated beds, and 
some thick beds contain graded graphite or graphitic intraclasts near the interlayers of graphitic slate. Slumping structures are common in the mixed fine-grained strata.

The cumulate lavas of the peridotitic komatiite are distinct flows with chilled margins, sometimes covered with lithic-vitric tuff rich in olivine and clinopyroxene crystals. Arenaceous epiclastics also are exposed in one or two outcrops.

From the above, Saverikko (1983) deduced that ultramafic volcanism, subsequent to and coeval with block faulting, resulted in extrusions separated by erosional intervals. The repeated discharge of blocky flows and prevalent ejecta produced lahars or, in the distal zone, subaqueous pyroclastic flows of turbidity currents (Saverikko 1983). Furthermore, the Kummitsoiva volcano grew up mainly in a subaerial environment through magmatic explosions, although the possibility of phreatomagmatic processes should not be discounted; steam eruptions require water, whose presence also beside the central vent is manifested by a small pillow breccia (Saverikko et al. 1985).

The Sotkaselkä komatiite complex is poorly known in internal structure but it resembles the Kummitsoiva complex in lithologic features (see Kallio et al. 1980) and arcuate structures (see Kallio 1980). The rocks are autobrecciated lavas and ejecta which pass from coarse-grained pyroclasts $(\varnothing<20 \mathrm{~cm})$ to tuffs or tuffites (Kallio et al. 1980). The lavas show gravitative differentiation as olivine-pyroxene cumulates and plagioclase(albitized)-bearing rocks in flows mainly of uniform mineral assemblage (Kallio et al. 1980). Some olivine-enstatite-augite cumulates are pillowed, indicating distinct flows of peridotitic komatiite (Kallio et al. 1980). Similar cumulates, but exhibiting layered magmatic structure, appear to form subvolcanic bodies, whose emplacement was controlled by block faulting (Kallio et al. 1980).

The abundance of pyroclastics (Lehtonen et al. 1985a) suggests that ultramafic volcanism was extrusive. The minor pillow lavas (Kallio et al.
1980) are indicative of water near the eruption center.

At Peltotunturi, the komatiites are amphibolechlorite rocks, serpentinite-peridotites and amphibolites closely associated with graphitic or calc-silicatic schists and cherty quartzites (Papunen et al. 1979). Overthrusting and other tectonic deformations have obliterated primary structures except some of those in the tuffaceous rocks (Meriläinen 1976; Papunen et al. 1979).

This major belt of komatiitic explosive volcanism extends into the USSR as the »Sattasvaaratype» komatiites of Kuolajärvi (Kulikov et al. 1980), and into northern Norway as the Bakkilvarri komatiites (see Fig. 3) which are similar to the rocks at Kummitsoiva and Sattasvaara (Wennervirta 1969; Henriksen 1983; Often 1985).

\section{Early-Proterozoic volcaniclastic komatiites}

The Svecofennian crustal segment includes within a volcanic arc at the south coast a chain of small ultramafic pods which display quite exceptionally volcanic breccias (Ehlers et al. 1986; Schreurs et al. 1986). But the pyroclastic komatiites are involved in the (Archaean) continental environment, and they have been documented from (1) Outokumpu in an allochthonous ophiolitic suite of $1.97 \mathrm{Ga}$ age (Koistinen 1981) at the continental borderland, and from (2) Rantasalmi as part of the $1.91-1.88$ Ga old volcanism (Vaasjoki and Sakko 1988) at or near the continental shelf break.

The Outokumpu serpentinite-dolomiteskarn-quartzite suite (A. Huhma 1975) with nickel and copper-cobalt ores (A. Huhma and M. Huhma 1970) (Fig. 10) is enclosed by the Kalevan turbiditic greywacke-slate sequence. The serpentinites were originally dunites with some peridotites and pyroxenites; the quartzite is a colloidal silica precipitate in parentage (A. Huhma 1975). The skarns, which are calc-silicate rocks, include metavolcanics (Park 1984; Rehtijärvi and Saastamoinen 1985) whose present composition may have changed as a result of leaching (Park 


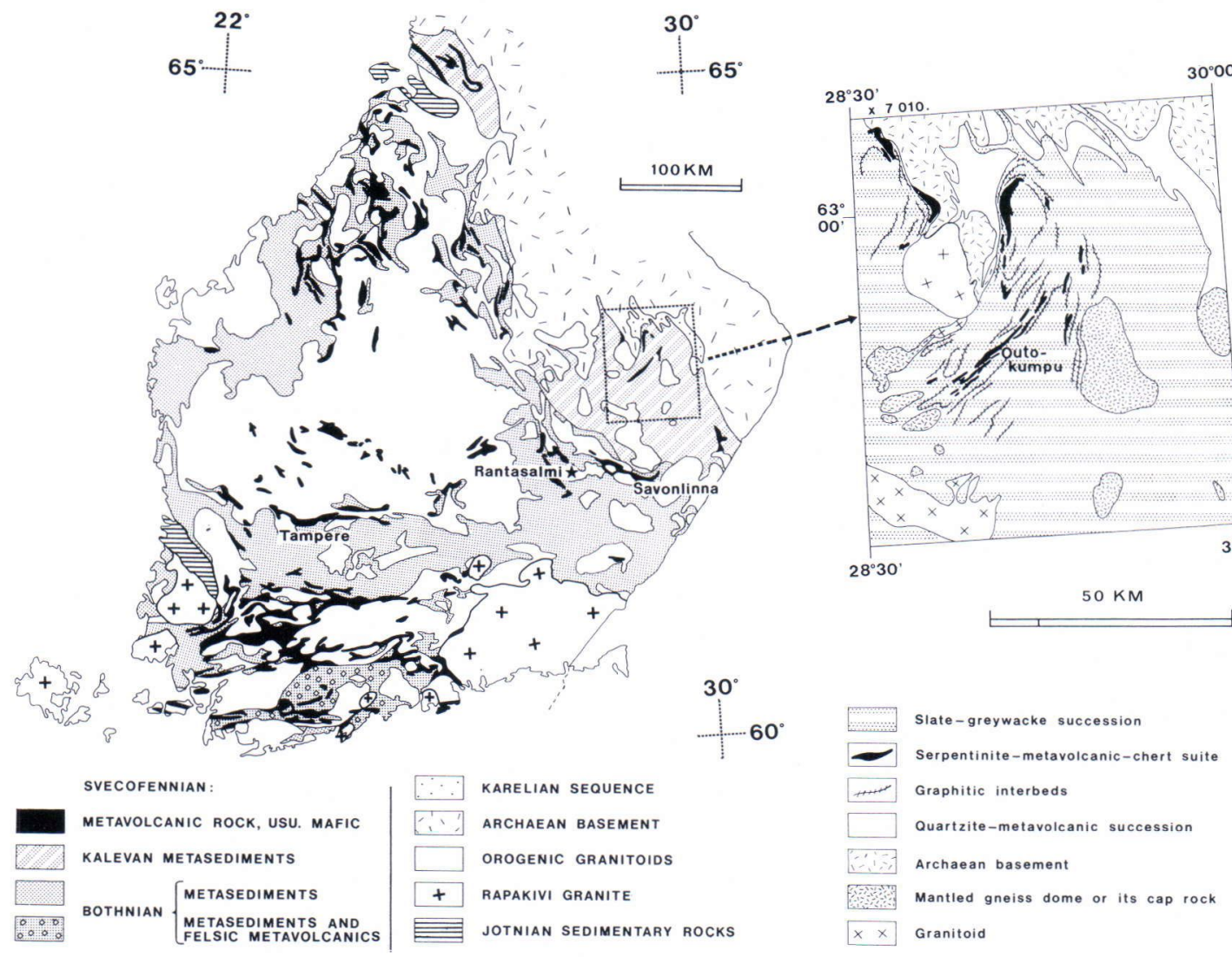

Fig. 10. Svecofennian volcanics (Simonen 1980; Luukkonen and Lukkarinen 1986), from which those at Rantasalmi and those associated with the Outokumpu rock suite are volcaniclastic komatiites. The Kalevan greywacky slates envelope the Outokumpu ophiolitic suite (A. Huhma 1975; Koistinen 1981) which is present in the form of serpentinite-metavolcanic-chert association.

1984): the impact of strong volcanic exhalations is seen in the extensive sulphide ores (Mäkelä 1974), and the effect of substantial metasomatic alterations is evidenced by the presence of dolomites (A. Huhma 1975) and chromiferous calcsilicate rocks (von Knorring et al. 1986). Their komatiitic affinity is apparent in the few remnants of spinifex(?) texture (Park 1984) and in REE and trace-elementary features (Rehtijärvi and Saastamoinen 1985). This large ophiolitic suite (Koistinen 1981) was thus preferably a serpentinite-volcanic-chert association. The serpentinites are derived from the residual mantle and cumulates (Vuollo and Piirainen 1989).
The voluminous metavolcanics at Outokumpu have preserved some rare primary structures such as mounds of tuffaceous pillow lavas that erupted from fissures together with hyalotuffbreccias of phreatic explosions (Park 1984). Shallow-water to terrestrial eruptions produced reworked fabrics and weak indications of air-fall deposits in the abundant ejecta (Park 1984). Several pyroxenites with vesicular margins disrupt the volcanic mounds and have supplied blocks for the tuff breccia: Park (1984) suggests that such lava domes had been the highly viscous crystal mush of fractured pyroxene. Low-pressure fractional crystallization features are en- 
countered in the flows of komatiitic basalt composition (Rehtijärvi and Saastamoinen 1985), which contains relics of clinopyroxene and olivine. The only proof of higher $\mathrm{MgO}$ content is in a hyalotuff, which may be due to interaction between volcanic glass and sea water enriched in magnesium (Park 1984).

At Rantasalmi, several pyroxene peridotitic komatiites are present in intercalations and discordant bodies within pillowed tholeiitic basalts (Kousa 1985). Mafic to felsic pyroclastics and a banded iron formation are found in the lower part of the volcanic assemblage (Makkonen and Ekdahl 1988). The komatiitic flows are massive but pillowed at the margins and associated with pyroclastic cover, mainly of coarse ejecta $(\varnothing<25 \mathrm{~cm})$ (Kousa 1985). Such lava flows with pyroclastic cover are built up by the non-explosive pouring of magma into water (deWit and Stern 1978). The mafic pillows, which include vesicles and central gas cavities (Kousa 1985; Makkonen and Ekdahl 1988), are suggestive of shallow-water conditions, and the local ultramafic to felsic pyroclasticity independent of magmatic composition is more likely due to phreatic than magmatic explosions.

\section{Tectonic setting}

The Raahe-Ladoga tectonic belt borders the northern Archaean domain in the Finnish bedrock. The Archaean domain is composed of the Saamian craton, the greenstone belts and younger granitic crustal contributions. If the Kalevan greywacky slates on the Karelian platformal cover have Archaean-Karelian residence age (H. Huhma 1987), they may be the provincial key to the continental shelf and slope. In the Kalevan province there are exposed also $\mathrm{Ar}$ chaean epicontinental metasediments (Gaál 1980) and the Siilinjärvi Archaean carbonatite (Puustinen and Kauppinen, in press) which is diagnostic of continental rift (see Best 1982, p. 204).

The Raahe-Ladoga belt (Fig. 11a) is deduced from Svecokarelian tectonics (see references in: Gaál 1986; H. Huhma 1986). But there is proof of Archaean tectono-magmatic activity: in addition to remnants of Archaean calc-alkaline volcanism (Kähkönen et al. 1986), it is certain that the Ilomantsi greenstone area with subalkaline to calc-alkaline metavolcanics (Tuukki et al. 1987), and also one or two other Archaean greenstone assemblages (Luukkonen and Lukkarinen 1986), underlap the Kalevan metasediments. In the Kuopio district, Talvitie (1971) recognized a regular fault net along which the Siilinjärvi Archaean carbonatite was emplaced, and Paavola (1984) described Archaean vertical fault-block movements; a notable tectono-metamorphic pulse culminated at $2.7 \mathrm{Ga}$ (Paavola 1988). Thus, marginal rifting started in the Archaean but was accelerated in Svecokarelian time.

This belt forks into the Skellefte and the Kiruna districts in Sweden (see Adamek and Wilson 1979, Witschard 1984). The Skellefte-RaaheLadoga belt has parallel crustal ruptures in the north (Fig. 11a). The deep-seated fracture system (e.g. Gaál et al. 1978), which continues as the Kuola(järvi)-Vygozero belt in the USSR (Zhuravlev et al. 1980), was tectonically operative during the Archaean in the form of the Kemin-Lappi rift (Saverikko 1988). The Kantalahti Archaean rift (Belyaev et al. 1977) forms the central trough of a subsidence, the original fault system having been much wider (Akudinov et al. 1972; Bylinski et al. 1977). The (Bjørnevann-) Pechenga-Imandra-Varzuga tectonic belt (Bugge 1980; Zhuravlev et al. 1980) is delineated by the Archaean-Proterozoic supracrustal rocks (Bugge 1980; Salop 1983, p. 172) present in elongated deposits. The Keivy fracture (Bogdanov et al. 1973) is a ridge of the Archaean linear mobile belt (Gorbunov et al. 1985a).

In Finland these rifts bound the subsided megablocks or crustal segments to the southwest (Talvitie 1977; Gaál 1982; Saverikko 1988). These show domal uplift consistent with the linear mantle upwelling (Fig. 11b) inferred by Saverikko (1987). The tectonic framework symmetric to 

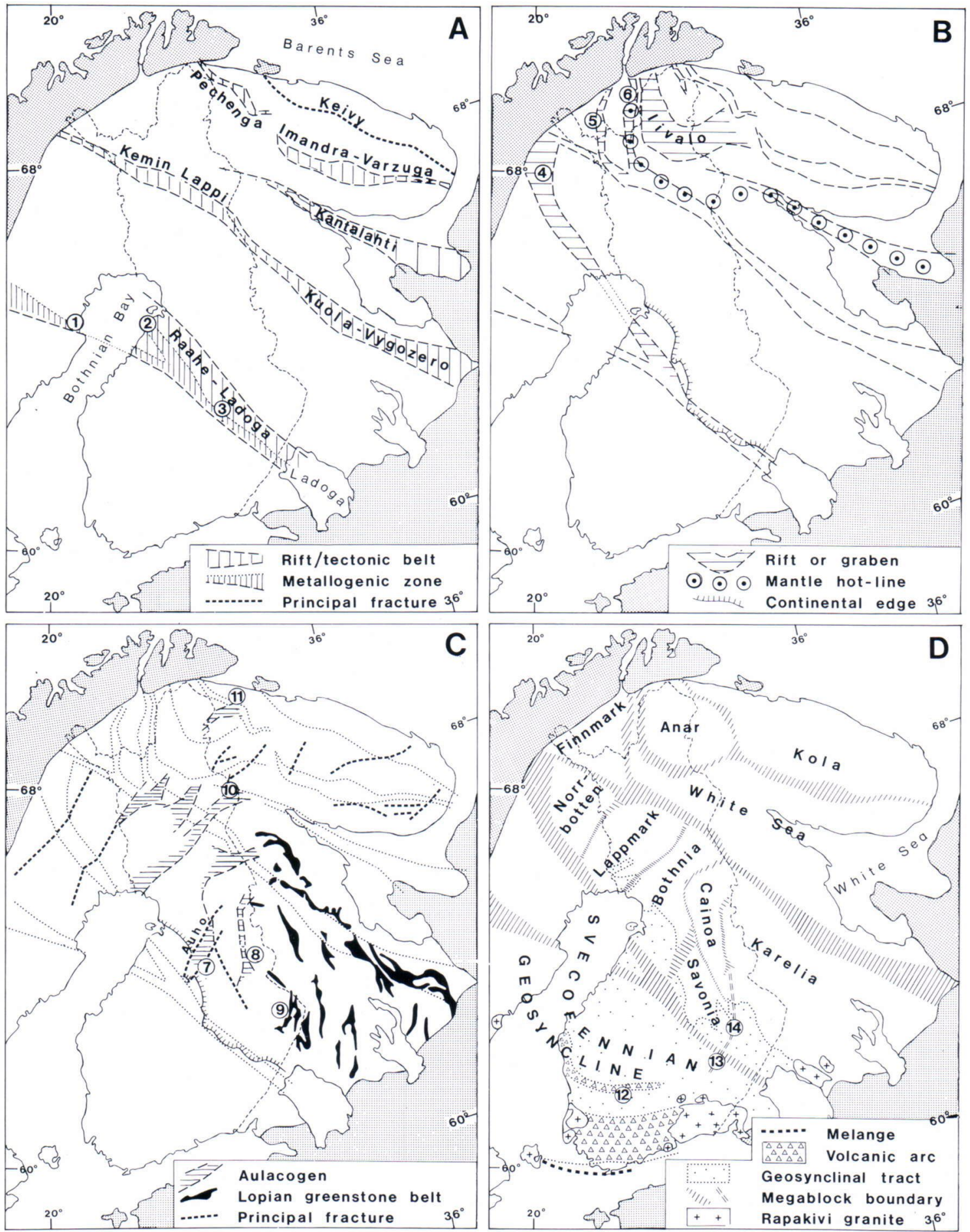

$500 \mathrm{~km}$

Paleozoic cover

Localities: A. 1. Skellefteá 2. Raahe 3.Kuopio/B. 4. Kiruna 5.Kautokeino 6.Karasjok/ C. 7. Otanmäki 8.Kuhmo 9.llomantsi 10. Sokli 11. Pechenga/D. 12.Tampere 13. Rantasalmi 14. Outokumpu. 
the mantle diapir is composed of the Kiruna(-Jällivaara) fault system (Witschard 1984), the Iivalo graben in the granulitic belt (Saverikko 1987 ; 1988), and the Kautokeino and Karasjok grabens (Krill 1985; Often 1985; Olesen and Solli 1985).

The Kuhmoan and Lopian greenstone belts (Fig. 11c), which are tectonic troughs of linear mobile belts between the crustal blocks (Martin et al. 1984; Musatov et al. 1984), evolved during more than one Archaean tectonic period (Gorbunov et al. 1985a, Lobach-Zhuchenko et al. 1986a, Luukkonen and Lukkarinen 1986). The absence of direct evidence of subduction may indicate Archaean crustal spreading without descending plates (Musatov et al. 1984), and sagduction was the more likely event in this intraplate diastrophism (Barbey and Martin 1987). Rybakov (1988) thinks in turn that a somewhat eugeosynclinal regime was achieved not until in late Lopian stage.

In the Lapland greenstone belt, the middle Lapponian metasediments occur in aulacogens, mostly on the bimodal metavolcanics (Saverikko 1987 ; 1988); other transverse tectonic basins linked to komatiitic volcanism will be defined in this paper. It is worth mentioning that the khondalite suite in the Iivalo graben ,that is the granulite belt, also belongs to the bimodal-volcanicarkose-slate association (Barbey et al. 1984).

The following diagonal fractures clarify the radial arrangement of these trench tracts (Fig. 11c). The northwestern breakup of the Norrbotten megablock can be established by geophysical sounding (Witschard 1984). In Finland, it is marked by an extensive mylonite zone of the gneissose basement complex and a parallel set of vertical diabases (Eilu 1984; Idman 1988), the komatiite at Sarvisoaivi (Korhonen 1981) and other schistose ultramafics (Idman 1988). The
Norrbotten-Lappmark megablock boundary follows major faults (Aarnisalo 1978; Kallio 1980; Hiltunen 1982; Witschard 1984) associated with the Lapponian subsidence (see Lanne 1979). The southeastern boundary of the Lappmark megablock has long been known from layered gabbro sheets, $2.44 \mathrm{Ga}$ old, and Svecokarelian subsidence (Perttunen 1985), but in the northeast the boundary has been affected by Lapponian faulting (see p. 22). The Bothnia and Savonia megablocks, that is, the two parts of the Iisalmi crustal segment of Väyrynen (1939), are separated from each other by a destructive depositional trap (Laajoki 1986a, b) which may be bounded by the Auho fault set (Laajoki 1986a) and an inferred fracture that includes the Otanmäki iron ore deposit (see Fig. 13b, p. 29); the basinal fill is lithostratigraphically comparable to the middle Lapponian (Laajoki 1986b).

In the Kola Peninsula, oblique crustal fissuring is seen in the Pechenga(-Pasvik-Vätsäri) greenstone belt and elongated Archaean intrusive zones (Gorbunov et al. 1985a). The ArchaeanProterozoic sequence (Meriläinen 1976; Bugge 1980; Salop 1983; p. 172) was deposited during one or more tectonic events involving syndepositional faulting in continental to marine environment (Zagorodny 1980; Boyd and Nixon 1985). The greenstone belt developed in a graben oriented across the rift and now showing the breach and the basinal fill, which increase in thickness to the northeast (Boyd and Nixon 1985; Gorbunov et al. 1985b).

\section{Archaean rift-aulacogen junctions}

The Archaean greenstone belts were generated by openings in the Saamian craton. The komatiites in the Kuhmo-Suomussalmi greenstone belt appear to be rarely, and only second-

Fig. 11. Tectonic belts in the Archaean crustal segment of the Fennoscandian Shield and their internal symmetry used as an indication of genetic linkage. The Bothnian-Kalevan provincial boundary is considered to indicate a continental shelf break. The Lopian greenstone belts are drawn after Papunen et al. (1985) and Lobach-Zhuchenko et al. (1986). The megablocks are called after provinces, except for the Kola and White Sea (Belomoria) megablocks, which are according to Soviet usage. 
arily, volcaniclastics, that is, phreatic in origin. This single-track trench may not attract so much attention as the Lapland greenstone belt, where voluminous komatiitic explosions were a distinct magmatic feature of upper Lapponian volcanism; here, too, the other komatiitic pulses were of minor importance. The initial komatiitic greenstones are too poorly exposed to indicate anything but deep-seated fracturing of the craton before the lower Lapponian cratonic sedimentation (Saverikko 1987). Above these metasediments, the Salla greenstone complex of bimodal volcanics implies very minor ultramafic extrusion. All these lower Lapponian komatiites occur in the Kemin-Lappi rift or in the Tuntsa-Sokli area (Fig. 12) where the fractures, not marked on the map, are part of the Kantalahti rift reactivated in Palaeozoic time (Paarma and Talvitie 1977).

Subsequent to the middle Lapponian continental rifting (Saverikko 1987; 1988), komatiitic explosive volcanism was active in the Pomokaira, Oraniemi, Keminniemi and Kitka-Oulanka areas. According to Kallio (1980), the boundary fractures of the Pomokaira trough fed ultramafic magma, and the komatiites extruded on its northern flank onto the Sotkaselkä complex. The Oraniemi aulacogen (Saverikko 1988) was linked to the Sattasvaara komatiite complex (Saverikko 1985): the bulk of the complex with the cinder cone is located at the rift-aulacogen junction. The previously known synclinal trough at Kitka-Oulanka (see Saverikko 1988) also includes komatiites (Kalliomäki 1985) which may, however, be lower or middle Lapponian; from the USSR, Kulikov et al. (1980) mentioned »Sattasvaara-type(?)» komatiites above the middle Lapponian metasediments (Saverikko 1987). The earlier discussion of the Keminniemi depression by Saverikko et al. (1985) is updated here.

The Kummitsoiva central-vent volcano developed at an intersection of the Kemin-Lappi rift and the Keminniemi trough. Its lateral vents, some of which appear now as coarser-clastic komatiites surrounded by tuffaceous rocks (see Juopperi 1986), opened on the northern border of the basin. The opposite border follows a fault zone which controls the $2.32 \mathrm{Ga}$ old gabbro stock (Manninen 1981) emplaced nearly vertically from the southeast (Mr. R. Pietilä, oral commun. 1988), and the Purkkivaara komatiite flow dipping to the northwest. This fracture also bounds the Tuntsan paragneisses, i.e. part of the Belomorian gneiss province (Gaál 1986), within the granite-gneiss complex (Juopperi 1986); it implies that fracturing may already have taken place during the Saamian diastrophism, if the Tuntsan paragneisses are not Lapponian in origin (see Saverikko 1987).

\section{Reactivated rift-aulacogen junction?}

A limited tectonic imbrication (Fig. 13c) developed within the Raahe-Ladoga tectonic belt and complicated the geological structure in the Outokumpu area (Gaál et al. 1975; Koistinen 1981). The tectonic belt was characterized by NW and N-trending fractures (e.g. Talvitie 1977). The N-S trending Archaean basement structures controlled the marginal fragmentation of the continent and early Proterozoic deposition, particularly in the Outokumpu area (Bowes et al. 1984). There appears to have been a wedge-sliced basin system, because Ward (1987) described the Höytiäinen depositional tract as having been initiated at 2.1 Ga and Koistinen (1986) postulated an embayment at Outokumpu with basinal events at 2.1-1.97 Ga (Park 1985); its head was linked to the Nunnanlahti(-Ipatti) Archaean greenstones, as shown by the cluster-ridges of mantled gneiss domes that represent ascension lines parallel to the basinal axis (Brun 1980).

This depressional wedge of sliced framework conjoins well to the Kuhmo-Suomussalmi palaeotectonic trench (Fig. 13b), which can be traced southward in the group of granitoids $2.75-2.66 \mathrm{Ga}$ old and in the tonalitized mica gneisses of Saamian or lower Kuhmoan origin (see Luukkonen and Lukkarinen 1986). The palaeotrench was reactivated $2.2-2.1 \mathrm{Ga}$ ago, extruding gabbro-wehrlite magma along the 

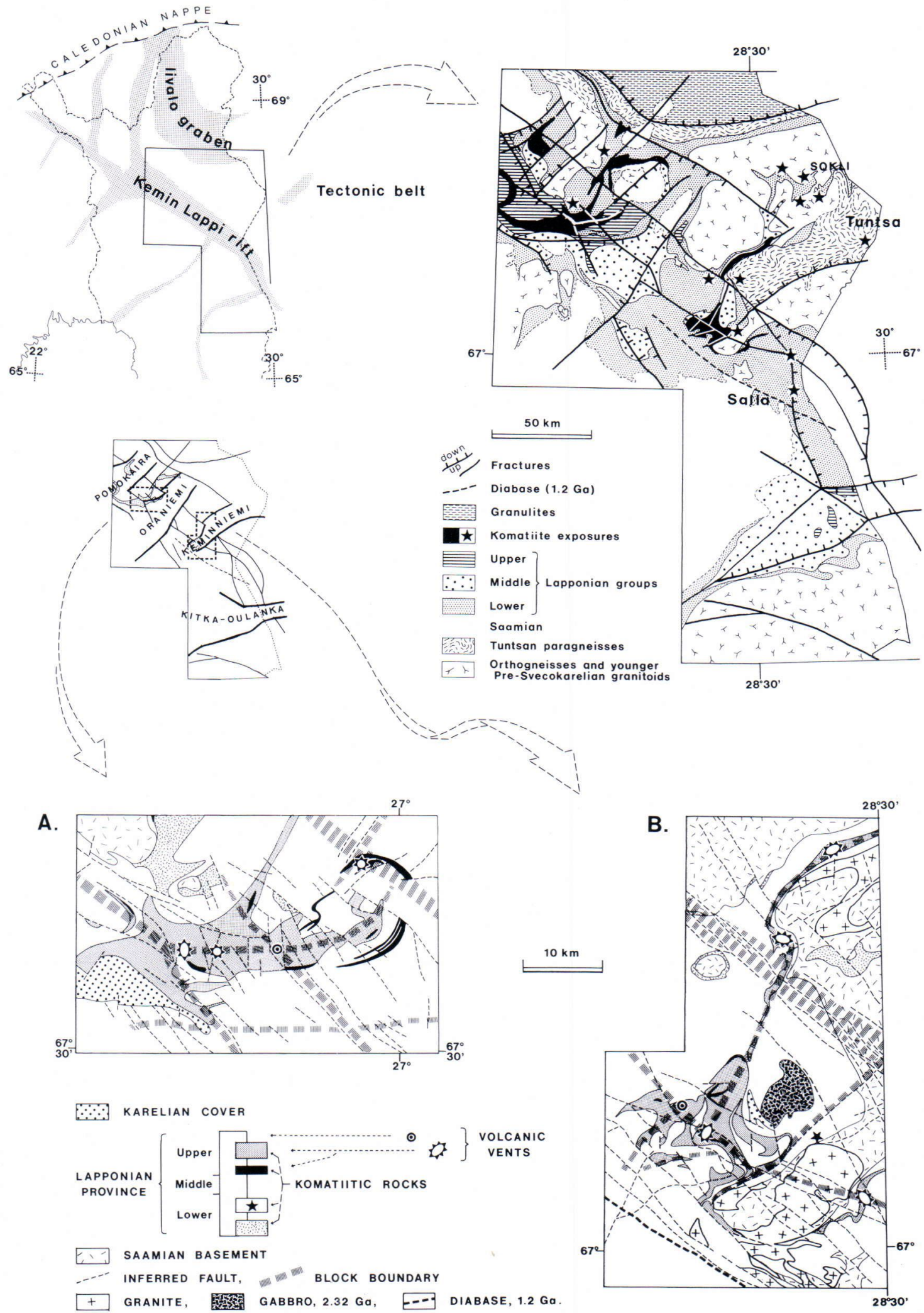

Fig. 12. The Kemin Lappi rift forms a tectonic framework for the Lapland greenstone belt (Saverikko 1988), but it is crosscut by the aulacogens at Pomokaira, Oraniemi, Keminniemi and Kitka-Oulanka. - A. Location of the Sattasvaara komatiite complex at the margin of the Oraniemi aulacogen (Saverikko 1985; 1988). — B. Link between the Kummitsoiva komatiite complex and the intersection of the rift and the Keminniemi aulacogen, revised after Saverikko and Manninen (1981) and Saverikko et al. (1985). 

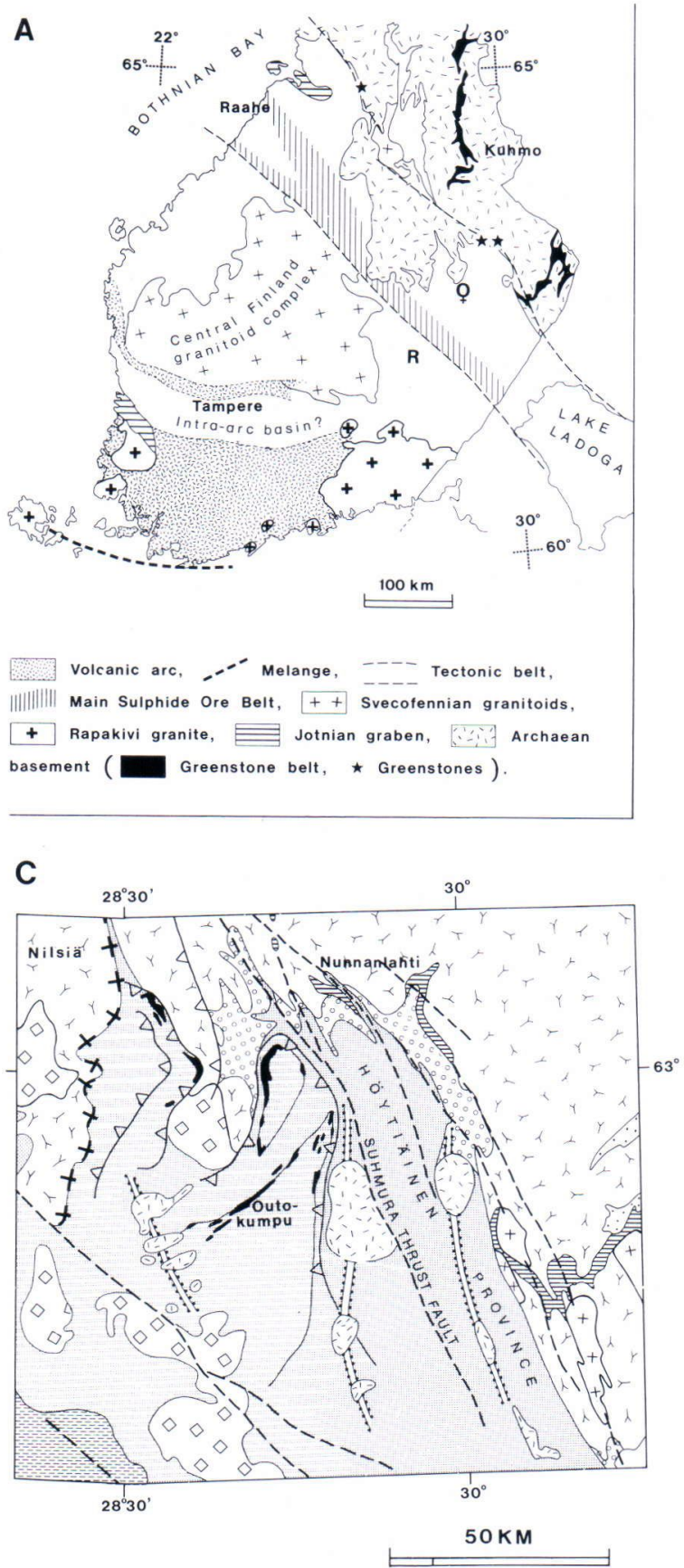

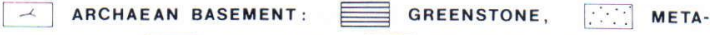
SEDIMENT, + GRANITOID, $\square$ MANTLED GNEISS DOME OR ITS CAP ROCK.

$[\because 00$ KARELIAN SEQUence, 1. $\square$ 2. $\square \square \square$ Kalevan (1.) SEQuence and (2.) allochthons, - Serpentinite-metavolCANIC-CHERT SUITE, BOTHNIAN PROVINCE, $\diamond$ GRANITOID.

- fracture, $\$ 4$ overthrust, $x$ collision line,
O Outokumpu

R Rantasalmi

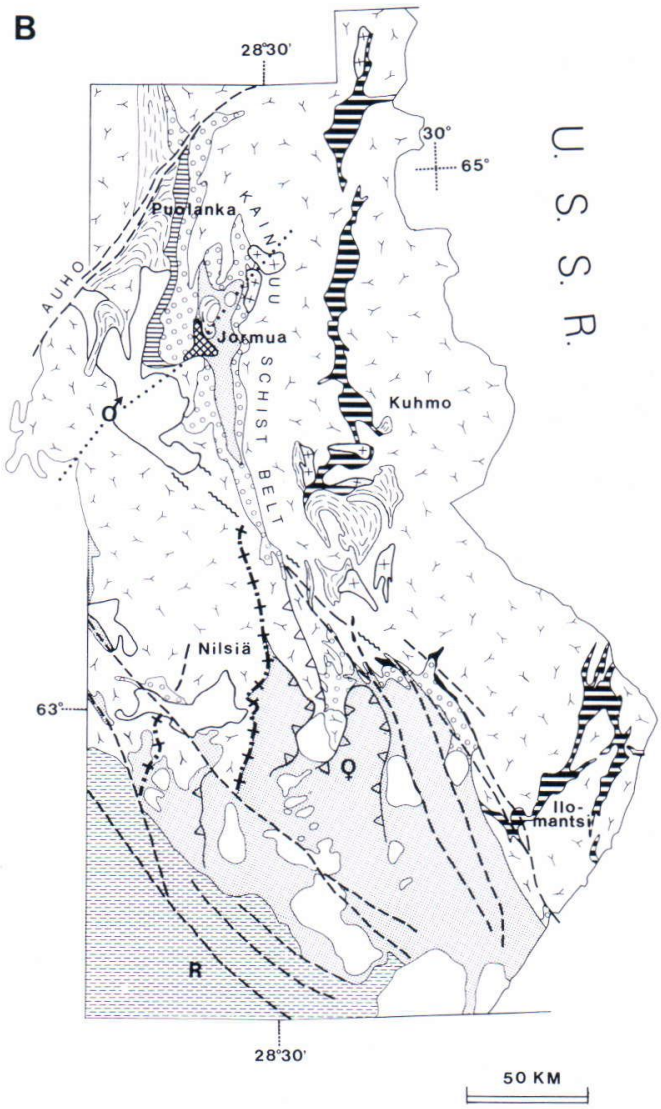

7 archaean basement: ?SaAmian paragneiss 三 greenstone belt, - Greenstone, + Gran ITOID INTRUSION, SEDIMENTS

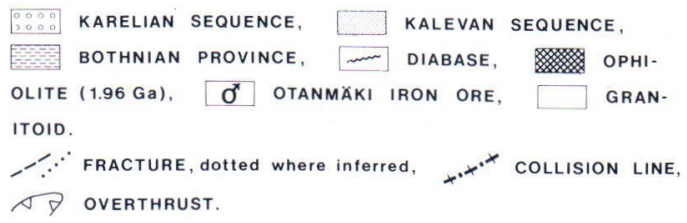

Fig. 13. A. Geosynclinal setting of the Svecofennian domain (see Saverikko, in review). - B. Location of the Outokumpu sulphide ore field on the continental shelf, separated from the Rantasalmi komatiites by the Main Sulphide Ore Belt (Kahma 1973) shown as a parallel wrench fault system. The map is compiled after Koistinen (1981), Laajoki (1986b), and Luukkonen and Lukkarinen (1986). - C. Tectonic imbrication within the continental margin framework in the Outokumpu area (Brun 1980; Koistinen 1981; 1986; Ward 1987). 
whole length of the greenstone belt proper (Piirainen 1985; Hanski 1986); the tectonic reactivation appears in field structures as shear zones along previous late Archaean fault sets (Luukkonen 1988).

The mantle origin of the Outokumpu suite (Stacey et al. 1977; Rehtijärvi and Saastamoinen 1985) is attributed to a mantle diapir (Park 1984). The concept of mantle upwelling is supported in the surroundings by the $1.96 \mathrm{Ga}$ old Jormua ophiolite (Fig. 13b) which also is accompanied by the Kalevan metasediments (Kontinen 1987). Short-lived mantle upwelling occurred here below an incipient intracontinental opening with a $\mathrm{N}$ to NW-trending half-graben framework, which was related to riftal processes and involved multiple sedimentation at $2.1-1.96 \mathrm{Ga}$ (Kontinen 1986; 1987).

The Jormua ophiolite lies within the extension of the suture, the nature of which has not been satisfactorily established and in which crustal shortening and the tectonic imbrication are confined to the Outokumpu area (Koistinen 1981). Koistinen (1981) associated the movement of the thrust nappe of the Outokumpu ophiolitic suite and the Kalevan greywacky slates with Svecofennian ocean closure. Because the Jormua province underwent the incipient intracontinental opening and approaches to that of a medium-size mantle plume in a continental setting described by Lambert (1981), the Outokumpu rock suite displaying terrestrial volcanic features may also be originated in hot-spot activity in a continental deepfault system.

The continental margin was fragmented, but palaeomagnetic data (Neuvonen et al. 1981) suggest that only the nearby Nilsiä(-Varpaisjärvi) basement fault-block moved relative to the environment in the Raahe-Ladoga tectonic belt. The Svecofennian pyroclastic komatiites at Outokumpu and Rantasalmi are aligned with the Kuhmo-Suomussalmi palaeotectonic trench reactivated. Prior to an exact determination of allochthonous displacements at Outokumpu, here is proposed that the reactivated Archaean rift-aulacogen junction controlled in one way or another the emplacement of the Outokumpu ophiolite. Indeed, the Rantasalmi komatiites lie in front(?) of the continental margin, where direct evidence for a Svecofennian oceanic crust is lacking.

\section{Plate-tectonic constraints}

\section{Continental plate}

Plate-tectonic models were applied to explain the evolution of the Finnish Archaean greenstone belts (e.g. Raith et al. 1982; Taipale 1983; 1988; Gaál 1986; Gaál and Gorbatschev 1987; Piirainen 1988). Nevertheless, geological arguments do not exclude intraplate rifting (see Martin et al. 1984; Barbey and Martin 1987; Saverikko 1987) which dominated the development of the Lopian greenstone belts in the USSR (Musatov et al. 1984; Rybakov 1988). The lower part of the greenstone-belt associations is characterized by bimodal metavolcanics and overlying terrigenous metasediments, which are indicative of cratonic rifting (see Condie 1982; p. 232).

The radial swarm of greenstone-belt trenches and crustal fractures may imply a net of aulacogens, a viewpoint that is consistent with domal uplift of the compact plate (Fig. 14). The palaeomagnetic data available do not indicate microplate drifts in the Fennoscandian Shield, at least not since $2.7 \mathrm{Ga}$ ago (Pesonen and Neuvonen 1981), even though the data are insufficient for the drawing of separate paths for the crustal blocks (Pesonen et al. 1989).

The Archaean crustal segment in Fennoscandia was fractured into an array of sialic megablocks, as was the continental crust in general at that time (Kröner 1981). Cwenan diastrophism involved some lateral movements of the sialic megablocks, causing, at least in the Lapland greenstone belt (see Saverikko 1987), the extensional stage of the Archaean greenstone-belt development of Goodwin (1981). 

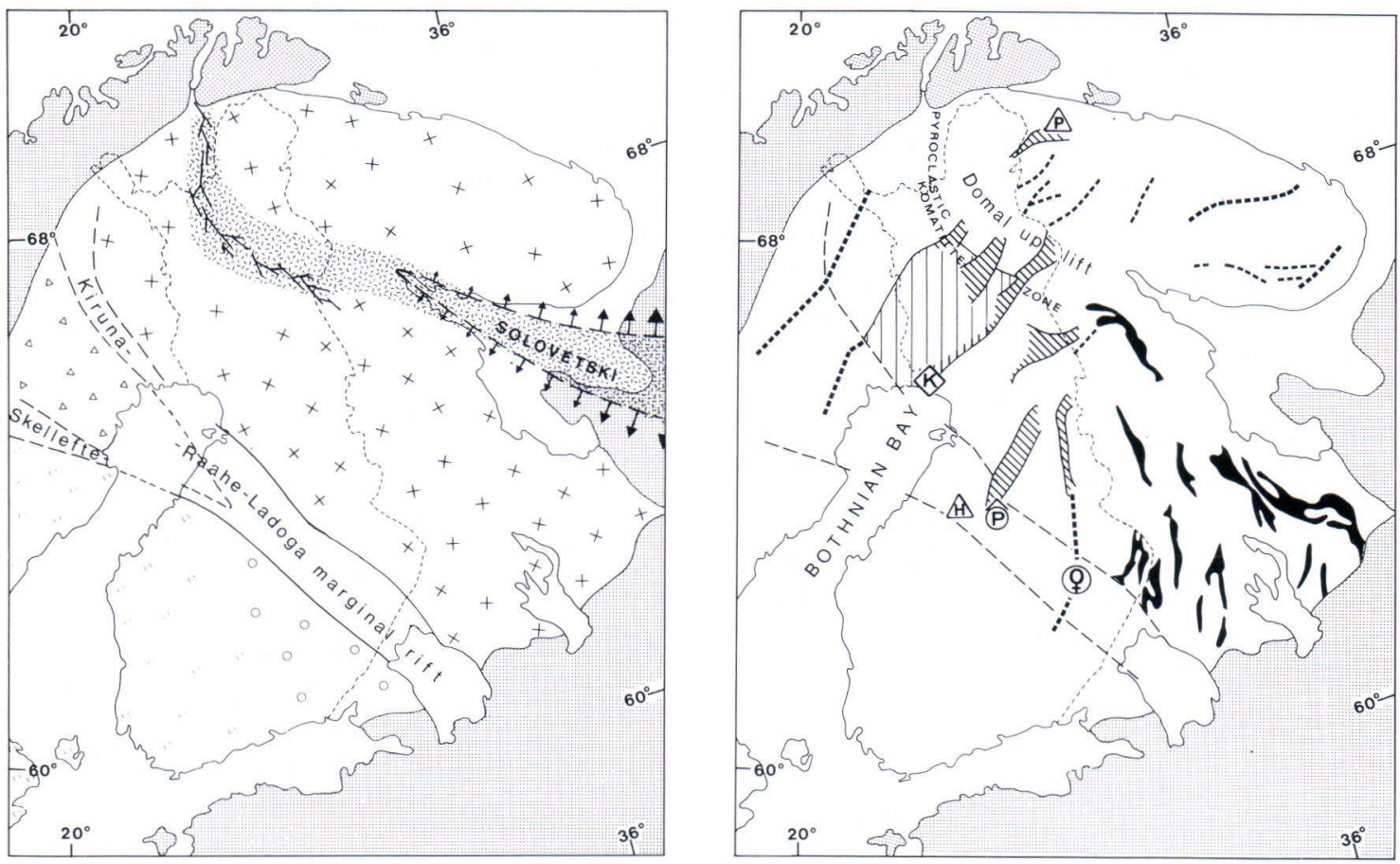

\section{$500 \mathrm{~km}$}

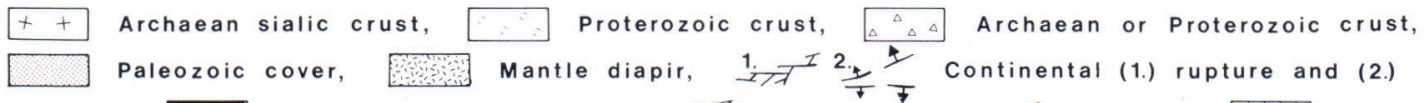

breakup, Lopian greenstone belt, Sulacoge $\vec{n}$,

megablock, (q) Outokumpu ophiolitic suite with sulphide ores,

(k) Layered gabbro-peridotite intru-

sion with chromite ores, at Kemi, \& Gabbro-wehrlite sheets with nickel ores, at Pechenga,

(A) Ultramafic stocks or plugs with nickel ores, at Hitura, (P) Volcanic massive sulphide ore at

Pyhäsalmi.

Fig. 14. Continental breakup and linear mantle diapir in connection with domal uplift in the Archaean continent. The margin is represented by the Skellefte fault system (Adamek and Wilson 1979) according to Lund (1987), or by the Kiruna (- Jällivaara) fault system (Witschard 1984) according to Öhlander et al. (1987). One or two Lopian greenstone belts lying along the Kuola(järvi) - Vygozero rift (see Fig. 11a) are separated from the belts that constitute a clearly radial swarm of intracontinental trenches. Some early Proterozoic magmatic ore deposits (see Papunen et al. 1986) appear to relate to Archaean rift—aulacogen junctions reactivated; the Pechenga Ni-Cu ore field lies in the (Bjørnevann-)Pechenga-Imandra-Varzuga tectonic belt (see Fig. 11a, c).

\section{Mantle diapir and continental breakup}

Linear mantle upwelling in northern Finland (Fig. 14), which manifests itself in upper Lapponian mantle-activated rifting, intensified the discharge of komatiites (Saverikko 1987), which host gold showings (Pulkkinen et al. 1986; Korkiakoski et al. 1988) and may have been a heat source for the mobilization of the gold in or into other Lapponian rocks (see Airas 1965; Ollila 1976; Pekkala and Puustinen 1978; Kuronen 1981; Inkinen 1985; Härkönen 1988; Pankka 
1988; Pankka and Vanhanen, in press). Karelian and Recent placer gold deposits (Stigzelius 1954; Härkönen 1983; 1988; Saarnisto and Tamminen 1987) all favor the palaeotectonic mantle-diapir area. The upper Lapponian mantle-activated rifting fits well in time and geologic past in with the development of $2.7 \pm 0.1 \mathrm{Ga}$ old riftal greenstone belts with high gold potential (see Groves et al. 1987).

The mantle upwelling corresponded well with the domal uplift. The pyroclastic komatiite centres at Kummitsoiva, Sattasvaara, and Sotkaselkä appear to resemble medium-size plumes at the beginning of the continental evolution, after the hot-spot model of Lambert (1981).

This komatiitic chain may be out-spaced in the USSR despite the occurrence of Belomorian komatiites with related pyroclastics (see Zagorodny 1988), where upwelling is apparent in the Solovetski mantle plume (Bylinski et al. 1977). The Belomorian succession may correspond stratigraphically with the Lopian and the Kuhmoan (Zagorodny 1988). In that case, the Belomorian appears to conjoin to the lowermiddle Lapponian in the lithostratigraphic features of the Tuntsa-Savukoski ultrametamorphic terrain (Saverikko 1987).

The early period of the Belomorian rifting was distinguished by tholeiitic magmatism (Efimov et al. 1977) and mantle diapirism (Bylinski et al. 1977), and the late period by superimposed transverse overthrusting of the strata (see below), which may reflect the southeasterly inclination of the White Sea megablock (see Saverikko 1987). The Solovetski mantle plume may be attributed to a large plume during the main to final stage of the hot-spot-continent interaction (see Lambert 1981), because it broke the crust and rotated the Kola megablock off the main continental segment (Bylinski et al. 1977).

The White Sea megablock formed a fracturebound palaeobasin in the ultrametamorphic complex of the Belomorian paragneisses, which are pelite-dominant in parentage and 3.3-2.7 Ga (Stenar 1972) or 2.9-2.7 Ga old (Tugarinov and
Bibikova 1980); Stenar (1988) reinterprets the depositional age to be older than $3.4 \mathrm{Ga}$. The fault system, which is in the form of wedging subsidence, is concentrated in the Kantalahti rift (Akudinov et al. 1972; Bylinski et al. 1977). The Archaean polyphase folding of high complexity (Stenar 1972; Ez et al. 1984) took place in two cycles under high-pressure metamorphism at different temperatures: the early period brought about NW-trending, i.e. longitudinal structures accompanied by mafic to ultramafic intrusions, whereas the late period caused recumbent isoclinal folds with a sublatitudinal hinge together with granitoid diapirism (Stenar 1972). The peak of the folding is dated at $2.7-2.6 \mathrm{Ga}$ (Ez et al. 1984; Gorokhov 1984). The granitoid diapirism of that generation is also recognizable in the TuntsaSavukoski high-grade metamorphic terrain (Gaál 1986) as well as in the Kuhmo-Suomussalmi greenstone belt (Luukkonen and Lukkarinen 1986).

Inasmuch as explosive volcanism is more characteristic of divergent or convergent plate margins than intraplate rifting proper (Fisher and Schmincke 1984, p.14), the upper Lapponian pyroclastic komatiite zone may denote the onset of continental breakup and, together with the Solovetski mantle plume, an embryonic stage of the Wilson cycle. But despite the anticlockwise rotation of the Kola megablock, which evolved since the Late Archaean, the divergence in amplitude is insignificant, even though it caused the southwesterly thrust of the granulitic belt in the Early Proterozoic (Bylinski et al. 1977; Efimov et al. 1977). This thrust may also have occurred at $2.5 \mathrm{Ga}$ (Meriläinen 1976).

\section{Quasi-collisional zone}

Barbey et al. (1984) and Marker (1985), however, regarded the overthrust of the granulites as an early Proterozoic continent-collisional structure on the basis of the assumed early Proterozoic origin of the granulitized rocks and the Karasjok greenstone-belt association (Barbey et al. 
1984; Krill et al. 1985). The more likely depositional age of the granulitic rocks may be $2.8-2.5$ $\mathrm{Ga}$ (Meriläinen 1976), and the rocks are Lapponian in parentage (Saverikko 1987); the age of the adjacent greenstone-belt association at Karasjok may be disputable. But the concept of the Archaean origin of the upper Lapponian komatiite zone, which adjoins the granulite belt (Fig. 15), should also take Archaean collision into account; that is, it is theoretically possible that in Archaean time the ultramafic oceanic crust underwent subduction (Arndt 1983) and thus brought about komatiitic volcanism (Allégre 1982).

In fact, the only direct evidence is for earlier continental rifting (Barbey et al. 1984) and for Archaean continental crust (H. Huhma 1986) beneath the granulitized epicontinental sediments (Barbey and Martin 1987). How could it be possible that an ultramafic (re)melt with high density contrast to granitic rocks (Nisbet 1982) ascends through a thick? continental crust without upthrust from the mantle itself? There are also no plate-tectonic deep-crustal structures, such as descending plate or tectonic crustal thickening in northern Finland (von Knorring and Lund 1989); instead the crustal thinning below the granulite belt accords well with the centre of domal uplift (see Fig. 14).

At any rate, the inferred suture at Kantalahti (Barbey et al. 1984) ruptures in the form of a rift circular megastructures of the granitoid basement (Bylinski et al. 1977), demonstrating the crustal breakup instead of the continent collision.

\section{Continental margin}

In the course of the Svecokarelian, the Skellefte-Raahe-Ladoga tectonic belt developed from the marginal rift into a Svecofennian suture (Gaál 1986; Gaál and Gorbatschev 1987) or intracontinental rift (Welin 1987). Park et al. (1984) point out similarities to a Cordilleran-type orogenic belt, since 2.1 Ga ago (Park 1985), whereas Vaasjoki and Sakko (1988) suggest different plate-tectonic processes closely related

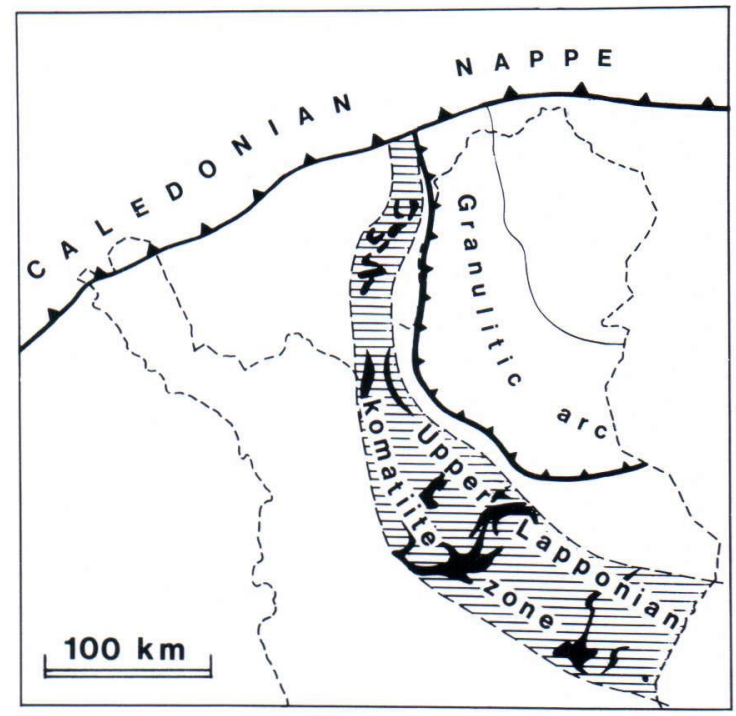

Fig. 15. The upper Lapponian komatiite zone adjoins the granulitized arc of the lower-middle Lapponian rocks, which is overthrust to the southwest.

in space and time at $1.93 \mathrm{Ga}$ to $1.85 \mathrm{Ga}$. The analogism to Phanerozoic evolution of the northeast Pacific margin (Park 1985) interests in that Phanerozoic komatiites, and boninites, appear not only in mid-oceanic or island-arc-subduction zones (Cameron and Nisbet 1982; Upadhyay 1982) but also in relatively stable continental margin (Wood 1980) settings.

The Raahe-Ladoga tectonic belt was in the form of a marginal rift at least until the onset of the Svecofennian system when the Outokum$\mathrm{pu}$ ophiolitic suite discharged at $1.97 \mathrm{Ga}$. At $1.90-1.86 \mathrm{Ga}$ there generated nickeliferous mafic-ultramafic rock bodies of continental affinity under moderate pressure (Mäkinen 1987). It was characterized also by $\mathrm{N}$-trending fractures, which partly controlled sedimentation (e.g. Bowes et al. 1984), and by high relief and rapid erosion, which were involved in the formation of the bulk of the Kalevan sediments (H. Huhma 1987). The marginal rift appears to have formed a basin-range structure at that time, and the Kalevan province approaches to a continental borderland palaeoenvironment, which was com- 


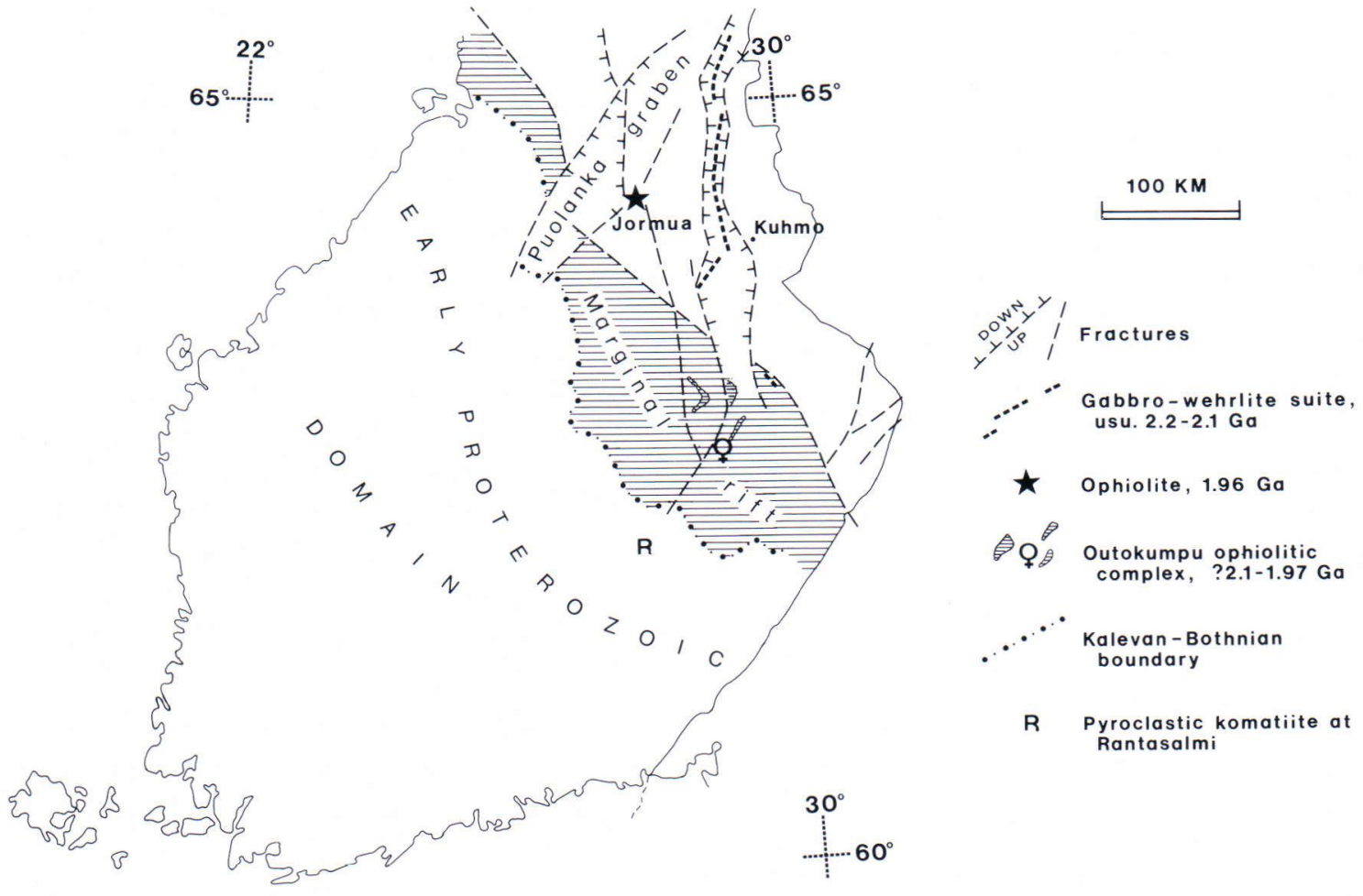

Fig. 16. Spatial, temporal and tectonic linkage between the Jormua ophiolite (Kontinen 1987), Outokumpu ophiolitic suite (Koistinen 1981), and gabbro-wehrlite intrusions (Piirainen 1985; Hanski 1986). Richard (1987) and Vaasjoki (1981) have determined model lead ages of $2.1 \mathrm{Ga}$ from the Outokumpu rock suite. Owing to Proterozoic tectonic processes, it may be futile to look for these inferred fractures in the marginal rift, where the Archaean tectonic signs in general are overprinted esp. by the NW-trending fractures of the Raahe-Ladoga belt.

posed of distinct depositional basins (Ward 1988) and where Jatulian-Kalevan (or Karelian-Svecofennian) unconformities are local in extent (see Simonen 1980).

Some of the transverse embayments are linked to the Archaean aulacogens. At Outokumpu, the ophiolite-related features may also anticipate the action of a medium-size mantle plume in a continental setting, according to the non-platetectonic hot-spot model of Lambert (1981). The Outokumpu ophiolitic suite lies at the intersection of the Raahe-Ladoga marginal rift and the reactivated Kuhmo-Suomussalmi palaeotectonic trench (Fig. 16). The mantle plume at Jormua ascended coincidentally through the intersection of the Jormua-Outokumpu half-graben and the
Puolanka graben, if the Jormua-Otanmäki fracture (see Fig. 13b) is actual as can be deduced, for instance, from the extra large kink in the strike of the Kainuu schist belt.

\section{Conclusion}

Komatiitic voicanism was virtually an Archaean phenomenon in Finland as elsewhere, but its explosive character is evident in shield dimensions only in the Fennoscandian Shield. Volcaniclastic komatiites appear in the Lapland and Kuhmo-Suomussalmi greenstone belts 3.0-2.5 $\mathrm{Ga}$ in maximum age span, but also in association with the $1.97 \mathrm{Ga}$ old Outokumpu ophiolite 
and as Rantasalmi komatiites erupted between $1.90 \mathrm{Ga}$ and $1.88 \mathrm{Ga}$ ago.

Four komatiitic eruption pulses are recognized in the Lapland greenstone belt: the first occurred after cratonization but before cratonic sedimentation; the second and third extreme eruptions were associated with the ensuing plateau-basalt volcanism. These ultramafic rocks with minor pyroclastics are insufficiently exposed and are the sole manifestation of deep-seated crustal fissuring in the lower Lapponian. The fourth pulse followed the middle Lapponian continental rifting, when the main pyroclastic komatiite zone formed in huge explosions of upper Lapponian mantleactivated rifting.

Magmatic, phreatomagmatic or phreatic explosions were associated with the discharge of all komatiitic rock species. But enigmatic high viscosity of the partial magma containing 18$30 \mathrm{wt} \% \mathrm{MgO}$ on an anhydrous basis (Saverikko 1983; 1985) was the reason why the pyroxene peridotitic komatiite caused explosive volcanism in the main pyroclastic zone in Lapland. Only minor phreatic komatiitic explosions occurred in the Kuhmo-Suomussalmi belt, which underwent sagduction in the ductile? periphery of the Saamian craton.

The Fennoscandian greenstone belts developed within the Saamian continent which cratonized at $3.1-3.0 \mathrm{Ga}$ and restabilized at $2.6 \mathrm{Ga}$. The greenstone belts form aulacogenic part of the radial swarm of crustal breakups, referring to domal uplift in a continental plate. Island-arc systems and other implications of the buoyancysubduction dualism are not easily adaptable for the craton-scale tectonic framework.

In Finland, the Lapland and the KuhmoSuomussalmi greenstone belts were tracts of three-period deposition which evolved from cratonic sedimentation and/or continental rifting to oceanic or mantle-activated rifting. The reverse stratigraphic order to that of the classic Archaean greenstone belt (Anhaeusser 1971), which is seen in upwards increasing amounts of komatiites, may be ascribed to evolving mantle upwelling through the continental crust.

The domal uplift was in connection with linear mantle upwelling which is inferred from the Lapponian pyroclastic komatiite zone together with the large Solovetski mantle plume in the USSR; central-vents of the komatiitic complexes at Kummitsoiva, Sattasvaara, and Sotkaselkä opened at rift-aulacogen intersections. They imply incipient divergence of the continental plate, resembling the embryonic stage of the Wilson cycle. The lower Lapponian komatiites, which lie inside or adjacent to the upper Lapponian mantlediapir area, may show the beginning of the mantle diapirism, which should have been excessively prolonged in the Archaean when compared with Phanerozoic plate-tectonic principles.

Continental rifting was no exception even at 3.0 Ga (see Burke et al. 1985) but the Archaean development of the aulacogens is still worth mentioning (cf. Windley 1984 , p. 87). Mantle-activated rifting $2.7-2.6 \mathrm{Ga}$ ago appears to have been linked to the most important Archaean period of global magmatic activity (see Condie 1981 , p. 43); the greenstone belts with high gold potential, in which the Lapland greenstone belt appears to belong, developed in riftal processes under conditions of high crustal extension (see Groves et al. 1987). In general, the extensional tectonic regime have been responsible for komatiitic volcanism, at a time when some forces were pulling the continental nuclei apart (Nisbet 1982).

After the Karelian (2.5-2.0 Ga) anorogenic period, hot-spot activity produced two ophiolites at $1.97-1.96 \mathrm{Ga}$ in the continental borderland, which shows palaeogeographic signs of a basinrange structure in the Raahe-Ladoga tectonic belt. Only one of the two medium-size mantle plumes ascended with komatiites, the ejecta of which possess attributes of phreatic explosions and air-fall deposits in the Outokumpu ophiolitic suite. The environment was that of a shallow-water to terrestrial setting, but because of the 
tectonic imbrication this crustal opening is not known very well.

At the Svecofennian orogenic peak 1.90-1.87 $\mathrm{Ga}$ ago (H. Huhma 1986), the Rantasalmi komatiites discharged at the Archaean continental shelf break, while the explosions may have resulted in the non-explosive pouring of the lava into water.

Acknowledgements. I am grateful for the editorial guidance of Dr. P. Nurmi, Editor of the Bulletin.

\section{References}

Aarnisalo, J., 1978. Use of satellite pictures for determining major shield fractures relevant for ore prospecting, northern Finland. Geol. Surv. Finland Rep. Invest. 21.

Adamek, P.M. \& Wilson, M.R., 1979. The evolution of a uranium province in northern Sweden. Phil. Trans. R. Soc. London A 291, 355-368.

Airas, K., 1965. Kuusamon Apajalahden kultamalmin ja sen lähiympäristön geologiaa. M.Sci. Thesis, Dept. Geol., Univ. Helsinki.

Akudinov, S.A.; Bolgurtsev, N.N.; Litvinenko, I.V. \& Porotova, G.A., 1972. Deep structure of the eastern part of the Karelian region (from joint geophysical studies of the Lake Onega-White Sea profile). Geotectonics 5, 296-297.

Allégre, C.J., 1982. Genesis of Archaean komatiites in a wet ultramafic subducted plate. In Arndt, N.T. and Nisbet, E.G. (eds) Komatiites. George Allen \& Unwin, London. 495-500.

Anhaeusser, C.R., 1971. Cyclic volcanicity and sedimentation in the evolutionary development of the Archaean greenstone belts of shield areas. Spec. Publs Geol. Soc. Aust. 3, 57-70.

Arndt, N.T., 1983. Role of a thin, komatiite-rich oceanic crust in the Archean plate-tectonic process. Geology 11, $372-375$.

—; Francis, D. \& Hynes, A.J., 1979. The field characteristics and petrology of Archean and Proterozoic komatiites. Can. Mineral. 17, 147-169.

— \& Nisbet, E.G., 1982. What is komatiite?. In Arndt, N.T. and Nisbet, E.G. (eds) Komatiites. George Allen \& Unwin, London. 19-27.

Auvray, B.; Blais, S.; Jahn, B.-M. \& Piquet, D., 1982. Komatiites and the komatiitic series of the Finnish greenstone belts. In Arndt, N.T. and Nisbet, E.G. (eds) Komatiites. George Allen \& Unwin, London. 131-146.

Barbey, P.; Convert, N.J.; Martin, H.; Moreau, B.; Capdevila, R. \& Hameurt, J., 1980. Relationships between granite-gneiss terrains, greenstone belts and granulite belts in the Archaean crust of Lapland (Fennoscandia). Geol. Rundsch. 69, 648-658.

-; Convert, J.; Moreau, B.; Capdevila, R. \& Hameurt, J., 1984. Petrogenesis and evolution of an early Proterozoic

collisional orogenic belt: The granulite belt of Lapland and the Belomorides (Fennoscandia). Bull. Geol. Soc. Finland $56,1-2,161-188$.

— \& Martin, H., 1987. The role of komatiites in plate tectonics tectonics. Evidence from the Archaean and early Proterozoic crust in the eastern Baltic Shield. Precambrian Res. 35, 1-14.

Belyaev, K.; Proskuryakov, V.; Korsakova, M.; Rabinovich, Y.; Zagorodny, V.; Bylinski, R. \& Dolivo-Dobrovlski, $A ., 1977$. The tectonic pattern of the eastern part of the Baltic Shield. In Kortman, C. (ed.) Fault Tectonics in the Eastern Part of the Baltic Shield. Proceedings of a Finnish-Soviet Symposium, 20th-24th September, 1976, Finland. 35-48.

Bernard-Griffiths, J.; Peucat, J.J.; Postaire, B.; Vidal, Ph.; Convert, J. \& Moreau, B., 1984. Isotopic data (U-Pb, $\mathrm{Rb}-\mathrm{Sr}, \mathrm{Pb}-\mathrm{Pb}$ and $\mathrm{Sm}-\mathrm{Nd}$ ) on mafic granulites from Finnish Lapland. Precambrian Res. 23, 325-348.

Best, M. G., 1982. Igneous and Metamorphic Petrology. W.H. Freeman and Company, San Francisco.

Binns, R.A.; Hallberg, J.A. \& Taplin, J.H., 1982. Komatiites in the Yilgarn Block, western Australia. In Arndt, N.T. and Nisbet, E.G. (eds) Komatiites. George Allen \& Unwin, London. 117-130.

Bogdanov, A.A.; Mouratov, M.V.; Khaine, V.E.; Koltchanov, V.P.; Leonov, Y.G. \& Tchernook, S. V. (compilers), 1973. International Tectonic Map of Europa and Adjacent Areas, 1:2 500 000. Unesco, Paris.

Bowes, D.R.; Halden, N.M.; Koistinen, T.J. \& Park, A.F., 1984. Structural features of basement and cover rocks in the eastern Svecokarelides, Finland. In Kröner, A. and Greiling, R. (eds) Precambrian Tectonics Illustrated. E. Schweizerbart'sche Verlagsbuchhandlung (Nägele u. Obermiller), Stuttgart. 147-171.

Boyd, R. \& Nixon, F., 1985. Norwegian nickel deposits; A review. In Papunen, H. and Gorbunov, G.I. (eds) NickelCopper Deposits of the Baltic Shield and Scandinavian Caledonides. Geol. Surv. Finland Bull. 333, 363-394.

Brun, J.-P., 1980. The cluster-ridge pattern of mantled gneiss domes in eastern Finland: Evidence for large-scale gravitational instability of the Proterozoic crust. Earth Planet. Sci. Lett. 47, 441-449.

Bugge, J.A.W., 1980. The Sydvaranger type of quartz-banded iron ore, with a synopsis of Precambrian geology and ore 
deposits of Finnmark. In Siivola, J. (ed.) Metallogeny of the Baltic Shield. Geol. Surv. Finland Bull. 307, 15-24.

Burke, K.; Kidd, W.S.F. \& Kusky, T.M., 1985. The Pongola structure of southeastern Africa: The world's oldest preserved rift?. J. Geodynamics 2, 35-49.

Bylinski, R.; Glebovitski, V.; Dolivo-Dobrovolski, A. \& Porotova, G., 1977. The major Belomorian deep-fault zone. In Kortman, C. (ed.) Fault Tectonics in the Eastern Part of the Baltic Shield. Proceedings of a FinnishSoviet Symposium, 20th-24th September, 1976, Finland. $49-62$.

Cameron, W.E. \& Nisbet, E.G., 1982. Phanerozoic analogues of komatiitic basalts. In Arndt, N.T. and Nisbet, E.G. (eds) Komatiites. George Allen \& Unwin, London. 29-50.

Cattell, A., 1987. Enriched komatiitic basalts from Newton Township, Ontario: Their genesis by crustal contamination of depleted komatiite magma. Geol. Mag. 124, 303-309.

Condie, K.C., 1981. Archean Greenstone Belts. Elsevier Scientific Publishing Company, Amsterdam-Oxford-New York.

—, 1982. Plate Tectonics and Crustal Evolution. 2nd Edition. Pergamon Press, New York-Toronto-OxfordSydney-Paris-Frankfurt.

deWit, M.J. \& Stern, C., 1978. Pillow talk. J. Volcanol. Geotherm. Res. 4, 55-80.

Echeverria, L.M. \& Aitken, B.G., 1986. Pyroclastic rocks: Another manifestation of ultramafic volcanism on Gorgona Island, Colombia. Contrib. Mineral. Petrol. 92, 428-436.

Efimov, M.M.; Koshechkin, B.I. \& Pavlovskiy, V.I., 1977. The geological structure and evolution of the Kandalaksha abyssal fault zone. In Kortman, C. (ed.) Fault Tectonics in the Eastern Part of the Baltic Shield. Proceedings of a Finnish-Soviet Symposium, 20th-24th September, 1976, 1976, Finland. 63-72.

Ehlers, C.; Lindroos, A. \& Jaanus-Järkkälä, M., 1986. Stratigraphy and geochemistry in the Proterozoic mafic volcanic rocks of the Nagu-Korpo area, SW Finland. Precambrian Res. 32, 297-315.

Eilu, P., 1984. Enontekiön Palovaaran-Järämän alueen geologiaa. M.Sci. Thesis, Dept. Geol., Univ. Turku.

Ez, V.V.; Gaft, D.E.; Geptner, T.M.; Kukley, L.N.; Kuznetsov, B.I. \& Morozov, Yu.A., 1984. Geological structures of some Precambrian complexes in the USSR. In Kröner, A. and Greiling, R. (eds) Precambrian Tectonics Illustrated. E. Schweizerbart'sche Verlagsbuchhandlung (Nägele u. Obermiller), Stuttgart. 319-334.

Fisher, R.V. \& Schmincke, H.-U., 1984. Pyroclastic Rocks. Springer-Verlag, Berlin-Heidelberg-New York-Tokyo.

Furnes, H., 1973. Variolitic structure in Ordovician pillow lava and its possible significance as an environmental indicator. Geology 1, 27-30.
Gaál, G., 1980. Geological setting and intrusion tectonics of the Kotalahti nickel-copper deposit, Finland. Bull. Geol. Soc. Finland 52, 1, 101-128.

-, 1982. Precambrian sedimentation and tectonics of the border zone between the Jatulian continent and the Svecokarelian geosyncline. In Sidorenko, A.V. (ed.) Sedimentary Geology of Highly Metamorphosed Precambrian Complexes. »Nauka» Publishing House, Moscow. $75-84$.

—, 1986. 2200 million years of crustal evolution: The Baltic Shield. Bull. Geol. Soc. Finland 58, 1, 149-168.

— \& Gorbatschev, R., 1987. An outline of the Precambrian evolution of the Baltic Shield. Precambrian Res. 35, 15-52.

—; Koistinen, T.\& Mattila, E., 1975. Tectonics and stratigraphy of the vicinity of Outokumpu, North Karelia, Finland. Geol. Surv. Finland Bull. 271.

—; Mikkola, A. \& Söderholm, B., 1978. Evolution of the Archean crust in Finland. Precambrian Res. 6, 199-215.

Gaskelberg, L.A.; Robonen, W.I. \& Zagorodny, V.G., 1986. Stratigraphy of the Sumian and Sariolan in the KarelianKola region. In Sokolov, V.A. and Heiskanen, K.I. (eds) Early Proterozoic of the Baltic Shield. Proceedings of a Finnish-Soviet Symposium, 19th-27th August, 1985, Petrozavodsk. 206-215.

Gèlinas, L.; Lajoie, J. \& Brooks, C., 1977. The origin and significance of Archean utramafic volcaniclastics from Spinifex Ridge, Lamotte Township, Québec. Geol. Soc. Assoc. Can. Spec. Paper 16, 297-309.

Goodwin, A.M., 1981. Archaean plates and greenstone belts. In Kröner, A. (ed.) Precambrian Plate Tectonics. Elsevier Scientific Publishing Company, Amsterdam-OxfordNew York. 105-135.

Gorbunov, G.I.; Zagorodny, V.G. \& Robonen, W.I., 1985a. Main features of the geological history of the Baltic Shield and the epochs of ore formations. In Papunen, H. and Gorbunov,G.I. (eds) Nickel-Copper Deposits of the Baltic Shield and Scandinavian Calodonides. Geol. Surv. Finland Bull. 333, 17-41.

—; Yakovlev, Yu.N.; Goncharov, Yu.V.; Gorelov, V.A.\& Tel'nov, V.A., 1985b. The nickel areas of the Kola Peninsula. In Papunen, H. and Gorbunov, G.I. (eds) NickelCopper Deposits of the Baltic Shield and Scandinavian Caledonides. Geol. Surv. Finland Bull. 333, 42-108.

Gorokhov, I.M., 1984. Rb-Sr geochronology of the eastern part of the Baltic Shield. In: Bogdanov, N.A. (ed.) Abstracts 2. 27th Int. Geol. Congr., 4th-14th August, 1984, Moscow. 302.

Groves, D.I.; Phillips, N.; Ho, S.E.; Houstoun, S.M. \& Standing, C.A., 1987. Craton-scale distribution of Archean greenstone gold deposits: Predictive capacity of the metamorphic model. Econ. Geol. 82, 2045-2058.

Gupta, A.; Basu, A. \& Ghosh, P.K., 1982. Ultramafic volcaniclastics of the Precambrian Dalma volcanic belt, 
Singhbhum, eastern India. Geol. Mag. 119, 505-510. Haimi, M., 1977. Luoston alueen geologia. M.Sci. Thesis, Dept. Geol., Univ. Helsinki.

Hanski, E., 1980. Komatiitic and tholeiitic metavolcanics of the Siivikkovaara area in the Archaean Kuhmo greenstone belt, eastern Finland. Bull. Geol. Soc. Finland 52, 1, $67-100$.

,- 1986 . The gabbro-wehrlite association in the eastern part of the Baltic Shield. In Friedrich, G.H.; Genkin, A.D.; Naldrett, A.J.; Ridge, J.D.; Sillitoe, R.H. and Vokes, F.M. (eds) Geology and Metallogeny of Copper Deposits. Springer-Verlag, Berlin-Heidelberg. 151-170.

Härkönen, I., 1983. The gold-bearing conglomerates of Kaarestunturi, central Finnish Lapland. In Foster, R.P. (ed.) Gold'82: The Geology, Geochemistry and Genesis of Gold Deposits. A.A. Balkema, Rotterdam. 239-247.

$\ldots, 1988$. Exploration of epigenetic and paleoplacer gold in the Central Lapland greenstone belt, Finland. In Goode, A.D.T.; Smyth, E.L.; Birch, W.D. and Bosma, L.I. (eds) Bicentennial Gold 88: Extended Abstracts, Poster Programme, 2. Geol. Soc. Aust. Abstr. Series 23, 530-532.

Helovuori, O., 1979. Geology of the Pyhäsalmi ore deposit, Finland. Econ. Geol. 74, 5, 1084-1101.

Henriksen, H., 1983. Komatiitic chlorite-amphibole rocks and mafic metavolcanics from the Karasjok greenstone belt, Finnmark, northern Norway: A preliminary report. Nor. Geol. Unders. Bull. 382, 17-43.

Hiltunen, A., 1982. The Precambrian geology and skarn iron ores of the Rautuvaara area, northern Finland. Geol. Surv. Finland Bull. 318.

Huhma, A., 1975. Suomen geologinen kartta, 1:100 000. Kallioperäkartan selitys. Lehdet-Sheets: 4222-Outokumpu, 4224-Polvijärvi, 4311-Sivakkavaara. Summary: Precambrian rocks of the Outokumpu, Polvijärvi and Sivakkavaara map-sheet areas. Geol. Surv. Finland, Espoo.

— \& Huhma, M., 1970. Contribution to the geology and geochemistry of the Outokumpu region. Bull. Geol. Soc. Finland 42, 1, 57-88.

Huhma, H., 1986. Sm-Nd, U-Pb and $\mathrm{Pb}-\mathrm{Pb}$ isotopic evidence for the origin of the Early Proterozoic Svecokarelian crust in Finland. Geol. Surv. Finland Bull. 337.

-, 1987. Provenance of early Proterozoic and Archaean metasediments in Finland: A Sm-Nd isotopic study. Precambrian Res. 35, 127-143.

Huppert, H.E. \& Sparks, R.S.J., 1985. Komatiites I: Eruption and flow. J. Petrol. 26, 694-725.

Idman, H., 1988. Geological Map of Finland, 1:100 000. PreQuaternary Rocks. Sheet-1832-Ropi. Geological Surv. Finland, Espoo.

Inkinen, O., 1985. Kittilän Sirkan kulta-kupariesiintymästä. Summary: Gold-copper occurrence at Sirkka, Kittilä. Geologi(Finland) 37, 8-11.

Jahn, B.M.; Vidal, P. \& Kröner, A., 1984. High-chronometric ages and origin of Archaean tonalitic gneisses in Finnish Lapland: A case for long crustal residence time. Contrib. Mineral. Petrol. 86, 398-408.

Jensen, L.S. \& Langford, F.F., 1985. Geology and petrogenesis of the Archean Abitibi Belt in the Kirkland Lake area, Ontario. Ontario Geol. Surv. Misc. Paper 123.

Juopperi, H., 1986. Geological Map of Finland, 1:100 000. Pre-Quaternary Rocks. Sheet-3733 + 4711-Savukoski. Geol. Surv. Finland, Espoo.

- \& Veki, A., 1988. The Archaean Tuntsa Supergroup in the Nuolusvaara area, northeastern Finland. Geol. Surv. Finland Spec. Paper 4, 145-149.

Kähkönen, Y.; Mattila, E. \& Nuutilainen, J., 1986. A revision of the Proterozoic-Archaean boundary of the Northern Bothnian schist belt with discussion of the geochemistry of related basic metavolcanics. Bull. Geol. Soc. Finland 58, 1, 109-129.

Kahma, A., 1973. The main metallogenic features of Finland. Geol. Surv. Finland Bull. 265.

Kallio, M., 1980. Keski-Lapin liuskealue Itä-Kittilän ja LänsiSodankylän osalta. Osa II: Rakenne ja stratigrafia. M.Sci. Thesis, Dept. Geol., Univ. Oulu.

—; Kärkkäinen, N. \& Sarapää, O., 1980. Keski-Lapin liuskealue Itä-Kittilän ja Länsi-Sodankylän osalta. Osa I: Petrografinen kuvaus ja kallioperäkartta. M.Sci. Thesis, Dept. Geol., Univ. Oulu.

Kalliomäki, J.H., 1985. Posion Riisitunturin-Noukavaaran alueen geologiasta Kuusamon liuskejakson länsiosassa. M.Sci. Thesis, Dept. Geol., Univ. Helsinki.

Karvinen, W.O., 1978. The Porcupine camp - a model for gold exploration in the Archean. Can. Min. J. 99, 9, $48-53$.

Kauniskangas, E., 1987. Savukosken koillisosan arkeeisten liuskeiden petrografia ja geokemia. Rep. 25, Res. Proj. Archaean areas, Dept. Geol., Univ. Oulu.

von Knorring, M. \& Lund, C.-E., 1989. The POLAR profile transect display. Tectonophysics $162,165-171$.

von Knorring, O.; Condliffe, E. \& Tong, Y.L., 1986. Some mineralogical and geochemical aspects of chromium-bearing skarn minerals from northern Karelia, Finland. Bull. Geol. Soc. Finland 58, 1, 277-292.

Koistinen, T., 1981. Structural evolution of an early Proterozoic strata-bound $\mathrm{Cu}-\mathrm{Co}-\mathrm{Zn}$ deposit, Outokumpu, Finland. Trans. R. Soc. Edinb. Earth Sci. 72, 115-158.

-, 1986. The Outokumpu ore district, East Finland, closed basin. In Sokolov, V.A. and Heiskanen, K.I. (eds) Early Proterozoic of the Baltic Shield. Proceedings of the Finnish-Soviet Symposium, 19th-27th August, 1985, Petrozavodsk. 104-112.

Kontinen, A., 1986. Early Proterozoic stratigraphy and sedimentation in the Hyrynsalmi area, eastern Finland. In Sokolov, V.A. and Heiskanen, K.I. (eds) Early Proterozoic of the Baltic Shield. Proceedings of the Finnish- 
Soviet Symposium, 19th-27th August, 1985, Petrozavodsk. 75-103.

-, 1987. An early Proterozoic ophiolite - the Jormua maficultramafic complex, northeastern Finland. Precambrian Res. 35, 313-341.

Korhonen, P., 1981. Enontekiön Sarvisoaivin nikkeliesiintymän petrologiasta, mineralogiasta ja geokemiasta. M.Sci. Thesis, Dept. Geol., Univ. Helsinki.

Korkiakoski, E.A.; Pulkkinen, E. \& Ward, P., 1988. Geochemical alteration, regional setting and structural control of the lower Proterozoic Pahtavaara Au-prospect, Finnish Lapland. In Goode, A.D.T.; Smyth, E.L.; Birch, W.D. and Bosma, L.I. (eds) Bicentennial Gold 88: Extended Abstracts, Poster Programme, 2. Geol. Soc. Aust. Abstr. Series 23, 190-192.

Kousa, J., 1985. Rantasalmen tholeiittisista ja komatiittisista vulkaniiteista. Summary: The tholeiitic and komatiitic metavolcanics in Rantasalmi, southeastern Finland. Geologi(Finland) 37, 17-22.

Kretschmar, U. \& Kretschmar, D., 1975. Geology and ultramafic flows of the Malartic Group, N.W. Que'bec. Geol. Soc. Am. Abstr. Programs 7, 801-802.

Krill, A.G., 1985. Svecokarelian thrusting with thermal inversion in the Karasjok-Levajok area of the northern Baltic Shield. Nor. Geol. Unders. Bull. 403, 89-101.

—; Bergh, S.; Lindahl, I.; Mearns, E.W.; Often, M.; Olerud, S.; Olesen, O.; Sandstad, J.S.; Siedlecka, A. \& Solli, A., 1985. $\mathrm{Rb}-\mathrm{Sr}, \mathrm{U}-\mathrm{Pb}$ and $\mathrm{Sm}-\mathrm{Nd}$ isotopic dates from Precambrian rocks of Finnmark. Nor. Geol. Unders. Bull. 403, 37-54.

Kröner, A., 1981. Precambrian plate tectonics. In Kröner, A. (ed.) Precambrian Plate Tectonics. Elsevier Scientific Publishing Company, Amsterdam-Oxford-New York. 57-90.

—; Puustinen, K. \& Hickman, M., 1981. Geochronology of an Archaean tonalitic gneiss dome in northern Finland and its relation with an unusual overlying volcanic conglomerate and komatiitic greenstone. Contrib. Mineral. Petrol. 76, 33-41.

Kulikov, V.S.; Galdobina, L.P.; Voinov, A.S.; Golubev, A.I.; Kashpirov, S.I.; Polehovsky, Yu.S. \& Svetov, A.P., 1980. Jatulian geology of the Paanajärvi-Kuolajärvi synclinorium. In Silvennoinen, A. (ed.) Jatulian Geology in the Eastern Part of the Baltic Shield. Proceedings of a Finnish-Soviet Symposium, 21st-26th August, 1979, Finland. 73-96.

—; Rybakov, S.L.; Berkovsky, A.N.; Chekulayev, V.P.; Krestin, E.M.; Sivoronov, A.A. \& Maliuk, B.I., 1984. Geology and metallogeny of the Archean greenstone belts in the basement of the East European platform. In Bogdanov, N.A. (ed.) Abstracts 2. 27th Int. Geol. Congr., 4th-14th August, 1984, Moscow. 337-338.

Kuronen, U., 1981. Kouervaaran sulfidiesiintymien geologisesta ympäristöstä Kuusamon liuskealueen länsiosassa, M.Sci. Thesis, Dept. Geol., Univ. Turku.

Laajoki, K., 1986a. The Precambrian supracrustal rocks of Finland and their tectono-exogenic evolution. Precambrian Res. 33, 67-85.

—, 1986b. The Central Puolanka Group - a Precambrian regressive metasedimentary sequence in northern Finland. Bull. Geol. Soc. Finland 58, 1, 179-193.

Lambert, R.St.J., 1981. Earth tectonics and thermal history: Review and a hot-spot model for the Archaean. In Kröner, A. (ed.) Precambrian Plate Tectonics. Elsevier Scientific Publishing Company, Amsterdan-Oxford-New York. $453-467$.

Lanne, E., 1979. Vuotoksen ja Kittilän alueiden geofysikaalisten tietojen tulkinnasta. Summary: On the interpretation of geophysical data from the Vuotos and Kittilä areas, northern Finland. Geol. Surv. Finland Rep. Invest. 25.

Lavikainen, S., 1977. Ilomantsin Ukkolanvaaran alueen kallioperän synnyn ja kehityksen tulkintaa. Licentiate Dissertation, Dept. Geol., Univ. Turku.

Lehtonen, M.; Manninen, T.; Rastas, P.; Väänänen, J.; Roos, S. \& Pelkonen, R., 1985a. Keski-Lapin geologisen kartan selitys. Summary and discussion: Explanation to the geological map of central Lapland. Geol. Surv. Finland Rep. Invest. 71.

—; Rastas, P. \& Väänänen, J., 1985b. Stratigraphic Map of Western Lapland, Northern Finland, 1:200 000. Geol. Surv. Finland, Espoo.

Lobach-Zhuchenko, S.B. \& Levchenkov, O.A., 1986. Isotope geochronological data on the Archaean-Lower Proterozoic boundary. In Sokolov, V.A. and Heiskanen, K.I. (eds) Early Proterozoic of the Baltic Shield. Proceedings of the Finnish-Soviet Symposium, 19th-27th August, 1985, Petrozavodsk. 191-198.

—; Levchenkov, O.A.; Chekulaev, V.P. \& Krylov, I.N., 1986. Geological evolution of the Karelian granite-greenstone terrain. Precambrian Res. 33, 45-65.

Lund, C.-E., 1987. Crustal structure along the northern 'FENNOLORA' profile. Precambrian Res. 35, 195-206.

Luukkonen, E., 1985. Structural and U-Pb isotopic study of late Archaean migmatitic gneisses of the Presvecokarelides, Lylyvaara, eastern Finland. Trans. R. Soc. Edinb. Earth Sci. 76, 401-410.

,- 1988 . The structure and stratigraphy of the northern part of the late Archaean Kuhmo greenstone belt, eastern Finland. Geol. Surv. Finland Spec. Paper 4, 71-96.

- \& Lukkarinen, H., 1986. Explanation to the stratigraphic map of Middle Finland. Geol. Surv. Finland Rep. Invest. 74.

Mäkelä, M., 1974. A study of sulfur isotopes in the Outokumpu ore deposit, Finland. Geol. Surv. Finland Bull. 267.

Mäkinen, J., 1987. Geochemical characteristics of Svecokarelian mafic-ultramafic intrusions associated with 
Ni-Cu occurrences in Finland. Geol. Surv. Finland Bull. 342.

Makkonen, H. \& Ekdahl, E., 1988. Petrology and structure of the early Proterozoic Pirilä gold deposit in southeastern Finland. Bull. Geol. Soc. Finland 60, 1, 55-66.

Manninen, T., 1981. Savukosken Akanvaaran alueen geologiasta. M.Sci. Thesis, Dept. Geol., Univ. Turku.

Marker, M., 1985. Early Proterozoic (c. 2000-1900 Ma) crustal structure of the northeastern Baltic Shield: Tectonic division and tectogenesis. Nor. Geol. Unders. Bull. 403, 55-74.

Marmo, J. \& Ojakangas, R.W., 1984. Lower Proterozoic glaciogenic deposits, eastern Finland. Geol. Soc. Am. Bull. 95, 1055-1062.

Martin, H., 1987. Evolution in composition of granitic rocks controlled by time-dependent changes in petrogenetic processes: Examples from the Archaean of eastern Finland. Precambrian Res. 35, 257-276.

-; Auvray, B.; Blais, S.; Capdevila, R.; Hameurt, J.; Jahn, B.M.; Piquet, D.; Quèrrè, G. \& Vidal, Ph., 1984. Origin and geodynamic evolution of the Archaean crust of eastern Finland. Bull. Geol. Soc. Finland 56, 1-2, $135-160$.

-; Chauvel, C.; Jahn, B.M. \& Vidal, Ph., 1983. Rb-Sr and Sm-Nd ages and isotopic geochemistry of Archaean granodioritic gneisses from eastern Finland. Precambrian Res. 20, 79-91.

— \& Quèrrè, G., 1984. A 2.5 Ga reworked sialic crust: Rb$\mathrm{Sr}$ ages and isotopic geochemistry of late Archaean volcanic and plutonic rocks from E Finland. Contrib. Mineral. Petrol. 85, 292-299.

McCall, G,J.H., 1973. Geochemical characteristics of some Archaean greenstone suites of the Yilgarn structural province, Australia. Chem. Geol. 11, 243-270.

Meriläinen, K., 1976. The granulite complex and adjacent rocks in Lapland, northern Finland. Geol. Surv. Finland Bull. 281.

,- 1980 . On the stratigraphy of the Karelian formations. In Silvennoinen, A. (ed.) Jatulian Geology in the Eastern Part of the Baltic Shield. Proceedings of a FinnishSoviet Symposium, 21st-26th August, 1979, Finland. 97-112.

Mikkola, E., 1941. Suomen geologinen yleiskartta. Kivilajikartan selitys. Lehdet-Sheets-B7-C7-D7, Muonio-Sodankylä- Tuntsajoki. General Geological Map of Finland. Summary: Explanation to the map of rocks. Geol. Surv. Finland, Espoo.

Muradymov, G.; Ivanov, N.; Pekkarinen, L. \& Hugg, R., 1988. Correlation and comparative description of Archean formations of Karelian and Lapland blocks in Finland. Geol. Surv. Finland Bull. Spec. Paper 4, 173-178.

Musatov, D.I.; Fedorovsky, V.S.; Afanasyev, Yu.T.A.; Zonenshain, L.P.; Kleshch, K.A.; Kovalev, A.A.; Mezhelovsky, N.V. \& Sorokhtin, O.G., 1984. Some aspects of geology and geological history of the USSR territory according to new geotectonic concepts. In Volkov, V.M.; Eremeev, A.N.; Kireev, A.S.; Krasny, L.I.; Kulikov, G.V.; Mezhelovsky, N.V. and Pushcharovsky, Yu.M. (eds) Geology of the USSR. 27th Int. Geol. Congr., 4th-14th August, 1984, Moscow. 129-145.

Neuvonen, K.J.; Korsman, K.; Kouvo, O. \& Paavola, J., 1981. Paleomagnetism and age relations of the rocks in the Main Sulphide Ore Belt in central Finland. Bull. Geol. Soc. Finland 53, 2, 109-134.

Nilsson, G., 1985. Nickel-copper deposits in Sweden. In Papunen, H. and Gorbunov, G.I. (eds) Nickel-Copper Deposits of the Baltic Shield and Scandinavian Caledonides. Geol. Surv. Finland Bull. 333, 313-362.

Nisbet, E.G., 1982. The tectonic setting and petrogenesis of komatiites. In Arndt, N.T. and Nisbet, E.G. (eds) Komatiites. George Allen \& Unwin, London. 501-520.

-; Bickle, M.J. \& Martin, A., 1977. The mafic and ultramafic lavas of the Belingwe greenstone belt, Rhodesia. J. Petrol. 18, 4, 521-566.

- \& Chinner, G.A., 1981. Controls of the eruption of mafic and ultramafic lavas, Ruth Well Ni-Cu Propect, West Pilbara. Econ. Geol. 76, 1729-1735.

Often, M., 1985. The Early Proterozoic Karasjok greenstone belt, Norway: A preliminary description of lithology, stratigraphy and mineralization. Nor. Geol. Unders. Bull. 403, 75-88.

Öhlander, B.; Skiöld, T.; Hamilton, P.J. \& Claesson, L.$\dot{A} ., 1987$. The western border of the Archaean province of the Baltic Shield: Evidence from northern Sweden. Contrib. Mineral. Petrol. 95, 4, 437-450.

Ojakangas, $R . W ., 1965$. Petrography and sedimentation of the Precambrian Jatulian quartzites of Finland. Geol. Surv. Finland Bull. 214.

Olesen, O. \& Solli, A., 1985. Geophysical and geological interpretation of regional structures within the Precambrian Kautokeino greenstone belt, Finnmark, North Norway. Nor. Geol. Unders. Bull. 403, 119-129.

Ollila, J.T., 1976. Mäkärärovan kultaesiintymän ja sen ympäristön geologiasta. M.Sci. Thesis, Dept. Geol., Univ. Helsinki.

Olsen, K.J. \& Nilsen, K.S., 1985. Geology of the southern part of the Kautokeino greenstone belt, West-Finnmark: $\mathrm{Rb}-\mathrm{Sr}$ geochronology and geochemistry of associated gneisses and late intrusions. Nor. Geol. Unders. Bull. 403, $131-160$.

Paakkola, J., 1971. The volcanic complex and associated manganiferous iron formation of the Porkonen-Pahtavaara area in Finnish Lapland. Geol. Surv. Finland Bull. 247.

Paarma, H. \& Talvitie, J., 1977. Deep fractures - Sokli carbonatite. In Kortman, C. (ed.) Fault Tectonics in the Eastern Part of the Baltic Shield. Proceedings of a Finn- 
ish-Soviet Symposium, 20th-24th September, 1976, Finland. 89-96.

Paavola, J., 1984. On the Archaean high-grade metamorphic rocks in the Varpaisjärvi area, central Finland. Geol. Surv. Finland Bull. 327.

- , 1986. A communication on the $\mathrm{U}-\mathrm{Pb}$ and $\mathrm{K}-\mathrm{Ar}$ age relations of the Archaean basement in the LapinlahtiVarpaisjärvi area, central Finland. Geol. Surv. Finland Bull. 339, 7-15.

-, 1988. The Archaean bedrock of the LapinlahtiVarpaisjärvi area, central Finland. Geol. Surv. Finland Spec. Paper 4, 161-169.

Page, M.L. \& Schmulian, M.L., 1981. The proximal volcanic environment of the Scotia nickel deposit. Econ. Geol. 76, $1469-1479$.

Page, $R$.W., 1978. Response of U-Pb zircon and Rb-Sr totalrock ages and mineral systems to low-grade regional metamorphism in Proterozoic igneous rocks, Mount Isa, Australia. Geol. Soc. Aust. 25, 141-164. (referred to in Piirainen 1985).

Pankka, H.S., 1988. Gold-bearing sulphide deposits in the Kuusamo early Proterozoic volcano-sedimentary belt, northeastern Finland. In Goode, A.D.T.; Smyth, E.L.; Birch,W.D. and Bosma, L.I. (eds) Bicentennial Gold 88: Extended Abstracts, Poster Programme 2. Geol. Soc. Aust. Abstr. Series 23. 165-167.

— \& Vanhanen. E., 1989. Aulacogen related epigenetic AuCo-U deposits in northeastern Finland. Geol. Surv. Finland Spec. Paper. 10, 91-94.

Papunen, H.; Gorbunov, G.I.; Boyd, R.; Nilsson, G.; Vorma, A.; Zagorodny, V. \& Robonen, W., 1985. General Geological Map of the Baltic Shield, 1:2 500 000. In Papunen, H. and Gorbunov, G.I. (eds) Nickel-Copper Deposits of the Baltic Shield and Scandinavian Caledonides. Geol. Surv. Finland Bull. 333.

-; Haapala, I. \& Rouhunkoski, P. (eds), 1986. Suomen Malmigeologia. Metalliset Malmiesiintymät. The Geological Society of Finland.

—; Häkli, T.A. \& Idman, H., 1979. Geological, geochemical and mineralogical features of sulfide-bearing ultramafic rocks in Finland. Can. Mineral. 17, 217-232.

Park, A.F., 1984. Nature, affinities and significance of metavolcanic rocks in the Outokumpu assemblage, eastern Finland. Bull. Geol. Soc. Finland 56, 1-2, 25-52.

-, 1985. Accretion tectonism in the Proterozoic Svecokarelides of the Baltic Shield. Geology 13, 725-729.

—; Bowes, D.R.; Halden, N.M. \& Koistinen, T.J., 1984. Tectonic evolution at an early Proterozoic continental margin: The Svecokarelides of eastern Finland. J. Geodynamics 1, 359-386.

Pekkala, Y. \& Puustinen, K., 1978. The chromian marbles of Kittilä, Finnish Lapland. Bull. Geol. Soc. Finland 50, $1-2,15-29$.

Pekkarinen, L.J., 1979. The Karelian formations and their depositional basement in the Kiihtelysvaara-Värtsilä area, East Finland. Geol. Surv. Finland Bull. 301.

Perttunen, V., 1985. On the Proterozoic stratigraphy and exogenic evolution of the Peräpohja area, Finland. Geol. Surv. Finland Bull. 331, 131-141.

Pesonen, L.J. \& Neuvonen, K.J., 1981. Paleomagnetism of the Baltic Shield - implications for Precambrian tectonics. In Kröner, A. (ed.) Precambrian Plate Tectonics. Elsevier Scientific Pulishing Company, AmsterdamOxford-New York. 623-648.

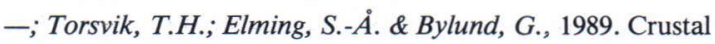
evolution of Fennoscandia - palaeomagnetic constraints. Tectonophysics 162, 27-49.

Pihlaja, P. \& Manninen, T., 1988. The metavolcanic rocks of the Peurasuvanto area, northern Finland. Geol. Surv. Finland Spec. Paper 4, 201-213.

Piirainen, T., (ed.) 1985. Arkeeisten alueiden malmiprojektin loppuraportti. Rep. 28, Res. Proj. Archaean Areas, Dept. Geol., Univ. Oulu.

-, 1988. The geology of the Archaean greenstone-granitoid terrain in Kuhmo, eastern Finland. Geol. Surv. Finland Spec. Paper 4, 39-51.

Pozhilenko, V.I., 1984. Stroyeniye i dannye k formatsionnoy kharakteristike Rikolatvinskoy zony Belomorya. In Geologiya i istoriya formirovaniya dokembriyskikh struktur Kolskogo poluostrova. Apatity, izd. Kolskogo fil. AN SSSR. 56-63. (referred to in Zagorodny 1988).

Pulkkinen, E.; Ollila, J.; Manner, R. \& Koljonen, T., 1986. Geochemical exploration for gold in the Sattasvaara komatiite complex, Finnish Lapland. In: Phillips, W.J. (ed.) Prospecting in Areas of Glaciated Terrain. Inst. Min. Met. London. 129-137.

Puustinen, K. \& Kauppinen, $H$., in press. Siilinjärvi carbonatite complex, eastern Finland. In Notholt, A.J.G. (ed.) Phosphate Deposits of the World. Cambrigde Univ. Press.

Path, M.; Raase, P. \& Hörmann, P.K., 1982. The Precambrian of Finnish Lapland: Evolution and regime of metamorphism. Geol. Rundsch. 71, 230-244.

Räsänen, J., 1977. Kaarestunturi-muodostuma ja sen sijainti Keski-Lapin liuskejaksossa. M.Sci. Thesis, Dept. Geol., Univ. Helsinki.

-, 1983. Keski-Lapin komatiiteista. English summary. Geologi (Finland) 35, 25-29.

-, 1984. On the Archean and Proterozoic komatiites in the Savukoski area, NE-Finland. In Armands, G. and Schager, S. (eds) Abstracts. 16e Nordiska Geol. Vintermötet, 9.-13. Januari 1984, Stockholm. 189.

-; Hanski, E. \& Lehtonen, M., 1986. Komatiites and tholeiites in the Möykkelmä area, northern Finland. In Lång, K. (ed.) Abstracts. 17e Nordiska Geologmötet, 12.-15.5.1986, Helsinki. 167.

Rastas, P., 1980. Stratigraphy of the Kittilä area. In Silvennoinen, A. (ed.) Jatulian Geology in the Eastern Part of 
the Baltic Shield. Proceedings of a Finnish-Soviet Symposium, 21st-26th August, 1979, Finland. 145-152.

Rehtijärvi, P. \& Saastamoinen, J., 1985. Tectonized actinolite-albite rocks from the Outokumpu district, Finland: Field and geochemical evidence for mafic extrusive origin. Bull. Geol. Soc. Finland 57, 1-2, 47-54.

Reitan, P.H., 1960. Windows in the Caledonides in the Ofoten district, Troms, and Finnmark. Main Precambrian area of western and central Finnmark. In: Holtedahl, O. (ed.) Geology of Norway. Nor. Geol. Unders. Bull. 208, 67-78.

Rickard, D.T., 1978. The Svecokarelian anomalous lead ore line. Geol. Foeren. Foerhandl. 100, 19-29.

Rybakov, S.I., 1988. Volcanism, sedimentogenesis and stratiform ore formation in the Archaean greenstone belts of Soviet Karelia. Geol. Surv. Finland Spec. Paper 4, 179-187.

— \& Lobach-Zhuchenko, S.B., 1981. Greenstone belts of the Fenno-Karelian craton. In Puustinen, K. (ed.) Geological, Geochemical and Geophysical Investigations in the Eastern Part of the Baltic Shield. 10th General Meeting of the Finnish-Soviet Joint Geological Working Group, 7th-11th September, 1981, Rovaniemi. 19-42.

Saarnisto, M. \& Tamminen, E., 1987. Placer gold in Finnish Lapland. Geol. Surv. Finland Spec. Paper 3, 181-194.

Salop, L.J., 1983. Geological Evolution of the Earth during the Precambrian. Springer-Verlag, Berlin-Heidelberg-New York.

Sarapää, O., 1980. Keski-Lapin liuskealue Itä-Kittilän ja Länsi-Sodankylän osalta. Osa III: Vulkaniittien geokemia. M.Sci. Thesis, Dept. Geol., Univ. Oulu.

Saverikko, M., 1983. The Kummitsoiva komatiite complex and its satellites in northern Finland. Bull. Geol. Soc. Finland 55, 2, 111-139.

,- 1985 . The pyroclastic komatiite complex at Sattasvaara in northern Finland. Bull. Geol. Soc. Finland 57, 1-2, $55-87$.

-, 1987. The Lapland greenstone belt: Stratigraphic and depositional features in northern Finland. Bull. Geol. Soc. Finland 59, 2, 129-154.

-, 1988. The Oraniemi arkose-slate--quartzite association: An Archaean aulacogen fill in northern Finland. Geol. Surv. Finland Spec. Paper 5, 189-212.

-, in review. (Early) Precambrian convection cell in the Fennoscandian Shield? Bull. Geol. Soc. Finland.

—; Koljonen, T. \& Hoffrén, V., 1985. Palaeogeography and palaeovolcanism of the Kummitsoiva komatiite complex in northern Finland. Geol. Surv. Finland Bull. 331, $143-158$.

— \& Manninen, T., 1981. Keminniemi/Saijan osa-alueen kivilajit, stratigrafia, rakenteet ja malmikriittiset vyöhykkeet. Rep. 8/81 (unpublished), Lapin Malmi, Rovaniemi.

-; Pulkkinen, E. \& Koljonen, T., 1983. Geochemical responce in till over komatiitic rocks. (Geological maps for the poster). In Björklund, A. and Koljonen, T. (eds) Abstracts. 10th Int. Geochem. Explor. Symp.-3rd Symp. Methods Geochem. Prospect., August 29- September 2, 1983, Espoo/Helsinki. 71-72.

Schreurs, J.; van Kooperen, P. \& Westra, L., 1986. Ultramafic metavolcanic rocks of early proterozoic age in WestUusimaa, SW Finland. N. Jahrb. Mineral. Abh. 155, 2, 185-201.

Sederholm, J., 1930. Några ord om berggrunden i Sydvaranger och närliggande delar av Finland. Geol. Foeren. Foerhandl. 52, 4, 435-454.

,- 1932 . On the geology of Fennoscandia with special reference to the pre-Cambrian. Geol. Surv. Finland Bull. 98.

Siedlecka, A., 1985. Geology of the Iesjavri-Skoganvarre area, northern Finnmarksvidda, North Norway. Nor. Geol. Unders. Bull. 403, 103-112.

—; Krill, A.G.; Often, M.; Sandstad, J.S.; Solli, A.; Iversen, E. \& Lieungh, B., 1985. Lithostratigraphy and correlation of the Archean and Early Proterozoic rocks of Finnmarksvidda and Sørvaranger district. Nor. Geol. Unders. Bull. 403, 7-36.

Silvennoinen, A., 1985. On the Proterozoic stratigraphy of northern Finland. Geol. Surv. Finland Bull. 331, 107-116.

-; Honkamo, M.; Juopperi, H.; Lehtonen, M.; Mielikäinen, P.; Perttunen, V.; Räsänen, J. \& Väänänen, J., 1980. Main features of the stratigraphy of North Finland. In Silvennoinen, A. (ed.) Jatulian Geology in the Eastern Part of the Baltic Shield. Proceedings of a FinnishSoviet Symposium, 21st-26th August, 1979, Finland. 153-162.

Simonen, A., 1971. Das finnische Grundgebirge. Geol. Runsch. 60, 4, 1406-1421.

-, 1980. The Precambrian in Finland. Geol. Surv. Finland Bull. 304.

Skålvoll, H., 1964. Preliminary results from the Pre-Cambrian of Finnmarksvidda. Nor. Geol. Tidskr. 44, 489-490.

Solli, A., 1983. Precambrian stratigraphy in the Masi area, southwestern Finnmark, Norway. Nor. Geol. Unders. Bull. 380, 97-105.

Stacey, J.S.; Doe, B.R.; Silver, L.T. \& Zartman, R.E., 1977. Plumbotectonics II A, Precambrian massive sulfide deposits. In Karpenko, S.F. (ed.) Geochronology and Problems of the Metallogeny. (in Russian). Nauka, Moscow. 93-106. (referred to in Helovuori 1979).

Stenar, M.M., 1972. Tectonic development of the Archean complex in Karelia (Belomorides of the western White Sea region). Geotectonics 5, 279-284.

-, 1988. Stratigraphy of Archaean deposits in Soviet Karelia. Geol. Surv. Finland Spec. Paper 4, 7-14.

Stigzelius, H., 1954. Gold occurrences in North Finland. Geol. Surv. Finland Geoteknillisiä Julkaisuja 55, 109-116.

Sun, S.-S. \& Nesbitt, R.W., 1978. Petrogenesis of Archaean 
ultrabasic and basic volcanics: Evidence from rare earth elements. Contrib. Mineral. Petrol. 65, 301-325.

Suslova, S.N., 1976. Komatiites in Lower Precambrian metavolcanic units of the Kola Peninsula. Dokl. Akad. Nauk. SSSR 228, 162-165.

Taipale, K., 1979. Arkeisen vulkanismin kehitys Tipasjärven alueella. Rep. 14, Kuhmo-Kittilä Res. Proj., Dept. Geol., Univ. Oulu.

—, 1983. The geology and geochemistry of the Archean Kuhmo greenstone-granite terrain in the Tipasjärvi area, eastern Finland. Acta Univ. Ouluensis Sci. Rerum. Nat. 151.

-, 1988. Volcanism in the Archaean Kuhmo greenstone belt, eastern Finland. Geol. Surv. Finland Spec. Paper 4, 151-160.

-; Hanski, E.; Kairakari, H. \& Piirainen, T., 1983. The Archaean Kuhmo greenstone belt. In Laajoki, K. and Paakkola, J. (eds) Exogenic Processes and Related Metallogeny in the Svecokarelian Geosynclinal Complex. Geol. Surv. Finland Guide 11, 4-33.

Talvitie, J., 1971. Seismotectonics of the Kuopio region, Finland. Geol. Surv. Finland Bull. 248.

-, 1977. The Ladoga-Bothnian Bay fracture zone. Dept. Geophys. Univ. Oulu Contrib. 92.

Tugarinov, A.I. \& Bibkova, E.V., 1980. Geochronology of the Baltic Shield according to the data of zirconometry. (in Russian). Acad. Sci. USSR, Nauka, Moscow. (referred to in Gaál 1986).

Tuokko, I., 1979. Kuhmon-Suomussalmen liuskejakson rautamuodostumat ja niiden stratigrafinen sijainti. Rep. 16, Kuhmo-Kittilä Res. Proj., Dept. Geol., Univ. Oulu.

Tuukki, P.A.; Männikkö, K.H.; Ojala, V.J. \& Pitkäjärvi, J.T., 1987. Koveron liuskejakson geologia. Rep. 9, North Karelia Res. Proj., Dept. Geol., Univ. Oulu.

Upadhyay, H.D., 1982. Ordovician komatiites and associated boninite-type magnesian lavas from Betts Cove, Newfoundland. In Arndt, N.T. and Nisbet, E.G. (eds) Komatiites. George Allen \& Unwin, London. 187-198.

Vaasjoki, M., 1981. The lead isotopic composition of some Finnish galenas. Geol. Surv. Finland Bull. 316.

-, 1988. Zircon $\mathrm{U}-\mathrm{Pb}$ versus $\mathrm{Rb}-\mathrm{Sr}$ whole-rock age data from eastern Finland: A critical comment on the papers of Barbey \& Martin and Martin in Precambrian Research, vol. 35, 1987. Precambrian Res. 39, 217-219.

— \& Sakko, M., 1988. The evolution of the Raahe-Ladoga zone in Finland: Isotopic constraints. Geol. Surv. Finland Bull. 343, 7-32.

Väyrynen, H., 1938. Petrologie des Nickelerzfeldes Kaulatunturi-Kammikivitunturi in Petsamo. Geol. Surv. Finland Bull. 116.

,- 1939 . On the geology and tectonics of the Outokumpu ore field and region. Geol. Surv. Finland Bull. 124

Veki, A., 1985. Sallan Nuolusvaaran konglomeraatti ja sen ympäristön kallioperän litostratigrafia ja rakenne. M.Sci. Thesis, Dept. Geol., Univ. Oulu.
Viljoen, M.J.; Viljoen, R.P.; Smith, H.S. \& Erlank, A.J., 1983. Geological, textural and geochemical features of komatiitic flows from the Komati formation. Spec. Publ. Geol. Soc. S. Afr. 9, 1-20.

Virransalo, P., 1985. Savukosken koillisosan kallioperän stratigrafia, rakenne ja metamorfoosi. M.Sci. Thesis, Dept. Geol., Univ. Oulu.

Vuollo, J. \& Piirainen, T., 1989. Mineralogical evidence for an ophiolite from the Outokumpu serpentinites in North Karelia, Finland. Bull. Geol. Soc. Finland 61, 1, 95-112.

Ward, $P$., 1987. Early Proterozoic deposition and deformation at the Karelian craton margin in southeastern Finland. Precambrian Res. 35, 71-93.

—, 1988. Early Proterozoic Kalevian lithofacies and their interpretation in the Hammaslahti-Rääkkylä area, eastern Finland. Geol. Surv. Finland Spec. Paper 5, 29-48.

Welin, E., 1987. The depositional evolution of the Svecofennian supracrustal sequence in Finland and Sweden. Precambrian Res. 35, 95-113.

Wennervirta, H., 1969. Karasjokområdets geologi. English summary. Nor. Geol. Unders. Bull. 258, 131-184.

Williams, D.A.C., 1979. The association of some nickel sulphide deposits with komatiitic volcanism in Rhodesia. Can. Mineral. 17, 337-349.

Windley, B.F., 1984. The Evolving Continents. 2nd edition. John Wiley \& Sons, Chichester-New York-BrisbaneToronto-Singabore.

Witschard, F., 1984. The geological and tectonic evolution of the Precambrian of northern Sweden - a case for basement reactivation?. Precambrian Res. 23, 273-315.

Wood, C.P., 1980. Boninite at a continental margin. Nature London 288, 692-694. (referred to in Cameron and Nisbet 1982).

Zagorodny, V.G., 1980. Jatulian geology of the Kola Peninsula. In Silvennoinen, A. (ed.) Jatulian Geology in the Eastern Part of the Baltic Shield. Proceedings of a Finnish-Soviet Symposium, 21st-26th August, 1979, Finland. 221-238.

-, 1988. The Archean supracrustal rocks of the Kola Peninsula. Geol. Surv. Finland Spec. Paper 4, 15-20.

—; Negrutsa, V.Z. \& Sokolov, V.A., 1986. Stratigraphy of Karelian deposits in the Karelia-Kola region. In Sokolov, V.A. and Heiskanen, K.I. (eds) Early Proterozoic of the Baltic Shield. Proceedings of the Finnish-Soviet Symposium, 19th-27th August, 1985, Petrozavodsk. 119-205.

Zhuravlev, V.; Ivanov, N.; Negrutsa, V.\& Pushkin, G., 1980. Prejatulian formations of the link zone between Karelides and Belomorides. In Silvennoinen, A. (ed.) Jatulian Geology in the Eastern Part of the Baltic Shield. Proceedings of a Finnish-Soviet Symposium, 21st-26th August, 1979, Finland. 239-251.

Received August 3, 1989

Revision accepted December 5, 1989 